\title{
Evaluation of the Near-Term
} Commercial Potential of Technologies Being Developed by the Office of Building Technologies

Volume I - Screening of Technologies
R. O. Weijo
D. L. Shankle
A. K. Nicholls
M. R. Anderson
S. A. Weakley
A. R. Anderson
R. L. Eckert

March 1991

Prepared for the U.S. Department of Energy under Contract DE-AC06-76RLO 1830

Pacific Northwest Laboratory Operated for the U.S. Department of Energy by Battefle Memorial Institute 


\title{
DISCLAIMER
}

This report was prepared as an account of work sponsored by an agency of the United States Government. Neither the United States Government nor any agency thereof, nor Battelte Memorial Institute, nor any of their employees, makes any warranty, expressed or implied, or assumes any legal liability or responsibility for the accuracy, completeness, or usefulness of any information, apparatus, product, or process disclosed, or represents that its use would not infringe privately owned rights. Reference herein to any specific commercial product, process, or service by Irade name, trademark, manufacturer, or otherwise does not necessarily constitute or imply its endorsement, recommendation, or favoring by the United States Government or any agency thereof, or Batteile Memorial Institute. The views and opinions of authors expressed herein do not necessarily state or reflect those of the United States Covernment or any agency thereof.

\author{
PACIFIC NORTHWEST LABORATORY \\ operated by \\ BATTELLE MEMORIAL INSTITLITE \\ for the \\ UNITED STATES DEPARTMENT OF ENERGY \\ under Contract DE-ACO6-76RLO 1830
}

\author{
Printed in the United States of America \\ Available to DOE and DOE contractors from the \\ Office of Scientific and Technical Information, P.O. Box 62, Oak Ridge, IN 37631; \\ prices available from (615) 576-8401. FTS 626-8401.
}

Available to the public from the National Technical Irformation Service, U.S. Department of Commerce, 5285 Port Royal Rd., Springfield, VA 22161. 
PNL -6778 Vol. I

UC-350

EVALUATION OF THE NEAR-TERM COMMERCIAL POTENTIAL OF TECHNOLOGIES BEING DEVELOPED BY THE OFFICE OF BUILDING TECHNOLOGIES

Volume I - Screening of Technologies
R. O. Weijo (a)
D. L. Shankle
A. K. Nicholls
M. R. Anderson
S. A. Weakley
A. R. Anderson
R. L. Eckert

March 1991

Prepared for

the U.S. Department of Energy

under Contract DE-AC06-76RLO 1830

Pacific Northwest Laboratory

Richland, Washington 99352

(a) Portland General Electric
Portland, Oregon 
.

\section{,}

, 


\section{EXECUTIVE SUMMARY}

This project developed an inventory of the Office of Building Techno]ogies (OBT) from a survey administered in 1988 to program managers and principal investigators from OBT. Information provided on these surveys was evaluated to identify equipment and practices that are near-term opportunities for technology commercialization and to determine whether they needed some form of assistance from OBT to be successful in the marketplace.

The near-term commercial potential of OBT technologies was assessed by using a technology selection screening methodology. The screening first identified those technologies that were ready to be commercialized in the next two years. The second screen identified the technologies that had a simple payback period of less than five years, and the third identified those that met a current need in the marketplace. Twenty-six OBT technologies met all the criteria.

These commercially promising technologies were further screened to determine which would succeed on their own and which would require further commercialization support. Additional commercialization support was recommended for OBT technologies where serious barriers to adoption existed or where no private sector interest in a technology could be identified.

Twenty-three technologies were identified as requiring commercialization support from OBT. These are categorized by each division within OBT and are shown in Table S.I.

The methodology used could easily be adapted to screen other DOEdeveloped technologies to determine commercialization potential and to allocate resources accordingly. It provides a systematic way to analyze numerous technologies and a defensible and documented procedure for comparing them. It is designed to be used in a dynamic environment so that changing parameters and needs can be incorporated. The process of evaluation should be ongoing; the procedure documented in this report is designed to be performed regularly and whenever the energy environment changes substantially. 
TABLE S.1. Technologies Requiring Commercialization Assistance from OBT Building Equipment Division

Optimized Ground-Coupled Heat Pump

Building Services Division

Core Commercial Daylighting

Friction Reduction Activities

Urban Heat Islands

Diagnostic Protocols and Analysis Methods

Radiant Barrier Climate Guide

Shared Savings

Strategies for Emerging Issues

Technology Assessment and Market Penetration

Building Systems Division

Roof Surface Treatment Guidelines

Aerated Autoclaved Concrete

Superlite

Advanced Residential Ventilation Systems

Moisture Guidelines for Residences

Multi-zonal Infiltration and Ventilation Measures

Perfluorocarbon Tracer System

Advanced Leakage Techniques

Sick Building Syndrome Protocol

Mathematical Modeling of Indoor Air Quality

HVAC/Lighting Interactions

Small office Buildings Handbook

Advanced Low-E Coating

Commercial Standards

Volume II of this study presents the full results of the equipment and practice survey of program managers and principal investigators. 


\section{CONTENTS}

EXECUTIVE SUMMARY $\ldots \ldots \ldots \ldots \ldots \ldots$ i $\ldots \ldots$

1.0 INTRODUCTION $\ldots \ldots \ldots \ldots \ldots \ldots . \ldots \ldots$

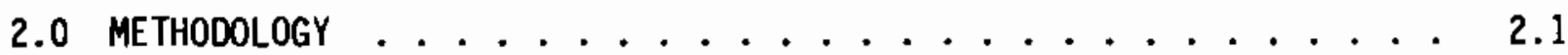

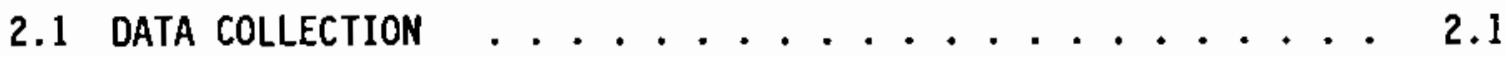

2.2 SCREENING CRITERIA . . . . . . . . . . . 2.2

2.3 DATA ANALYSIS ......................... 2.4

3.0 TECHNOLOGIES WITH NEAR-TERM COMMERCIAL PROMISE $\ldots \ldots \ldots . . . . .3$

3.1 DATE TECHNOLOGY IS READY FOR COMMERCIALIZATION . . . . . . 3.1

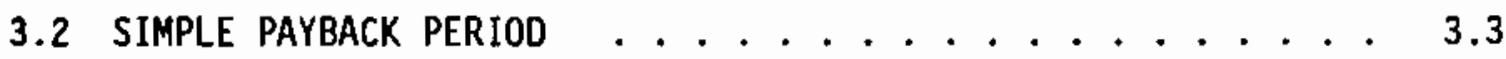

3.3 CURRENT NEEDS IN THE MARKETPLACE ........... 3.4

3.4 IDENTIFICATION OF NEAR-TERM PROMISING TECHNOLOGIES $\ldots \ldots . .3 .8$

4.0 TECHNOLOGIES THAT WILL SUCCEED ON THEIR OWN . . . . . . . 4. I

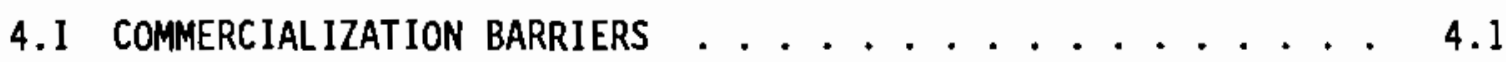

4.2 PRIVATE SECTOR INTEREST IN PROMISING TECHNOLOGIES . . . 4.2

4.3 SUMMARY ............................. 4.4

5.0 CONCLUSIONS AND RECOMMENDATIONS . . . . . . . . . . 5.1

6.0 REFERENCES $\ldots \ldots \ldots \ldots \ldots . \ldots \ldots \ldots \ldots$

APPENDIX A - EQUIPMENT AND PRACTICE FORM . . . . . . . . . A.1

APPENDIX B - RESULTS OF TECHNOLOGY SCREENING .......... B.I 


\section{FIGURES}

1.1 New Product DeveTopment Approach to Technology

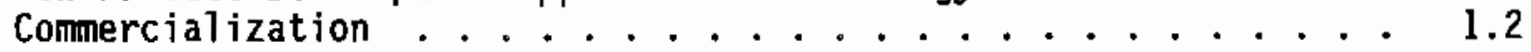

2.1 Technology Screening Model .............. 2.3

3.1 First Screen in the Technology Screening Model ........ 3.1

3.2 Second Screen in the Technology Screening Model . . . . . . 3.3

3.3 Third Screen in the Technology Screening Model . . . . . . 3.6

4.1 Fourth Screen in the Technology Screening Model ....... 4.2

4.2 Fifth Screen in the Technology Screening Model ....... 4.3 


\section{$\underline{\text { TABLES }}$}

S.1 Technologies Requiring Commercialization Assistance from OBT . . . iv

3.1 OBT Technologies that Will Be Ready for Commercialization With in Two Years . . . . . . . . . . . . . . 3.2

3.2 OBT Technologies that Have Simple Payback Periods of Five Years or Less and Will Be Ready for Commercialization Within Two Years $\quad 3.5$

3.3 OBT Technologies That Reduce Peak Energy Usage, Have Simple Payback Periods of Five Years or Less, and Will Be Ready for Comnercialization Within Two Years . . . . . . . . . . .

3.4 OBT Technologies That Provide Healthier Indoor Air Environments, Have Simple Payback Periods of Five Years or Less, and Will be Ready for Commercialization Within Two Years . . . . . . .

3.5 OBT Technologies That Are Commercially Promising in the Near-Term . . . . . . . . . . . . . . . 3.9

4.1 Comnercialization Barriers . . . . . . . . . . . . . 4.1

4.2 Technologies with Serious Barriers to Conmercialization . . . . 4.3

4.3 Technologies in which There is No Private Interest in Licensing or Using ................. 4.4

4.4 Technologies Requiring Assistance . . . . . . . . . . . 4.5 
'

,

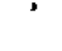




\subsection{INTRODUCTION}

The Office of Building Technologies (OBT) is developing a variety of technologies. A preliminary assessment conducted in FY 1988 identified over 100 types of equipment and practices now under development by OBT. Like other organizations involved in developing technologies, OBT can actively support the transfer of only a limited number of these. Pacific Northwest Laboratory (PNL) $^{(a)}$ has developed a mechanism to effectively screen and identify technologies that have near-term commercial promise.

Private corporations use new product development process to select technologies for further development. The process can provide insight into the information needs required for technology development in the federal government as we11. It helps managers identify and direct resources to those technologies having the highest probability of being commercially successful.

The academic 1iterature contains a number of new product development models (Crawford 1983; Urban and Hauser 1980). Although conceptual variations among these models exist, they function quite similarly and are consistent with the actual procedures employed in developing new products (see also Roberson and Weijo 1988).

Though the requirements for any specific technology can vary, a general model can be identified. One example of this process is highlighted in Figure 1.1. This process includes the following steps:

1. Identify technology applications

2. Screening

3. Concept testing and diagnostic evaluation

4. Marketing strategy

5. Business analysis

6. Product development

(a) Pacific Northwest Laboratory is operated for the U.S. Department of Energy by Battelle Memorial Institute under Contract DE-AC06-76RLO 1830. 


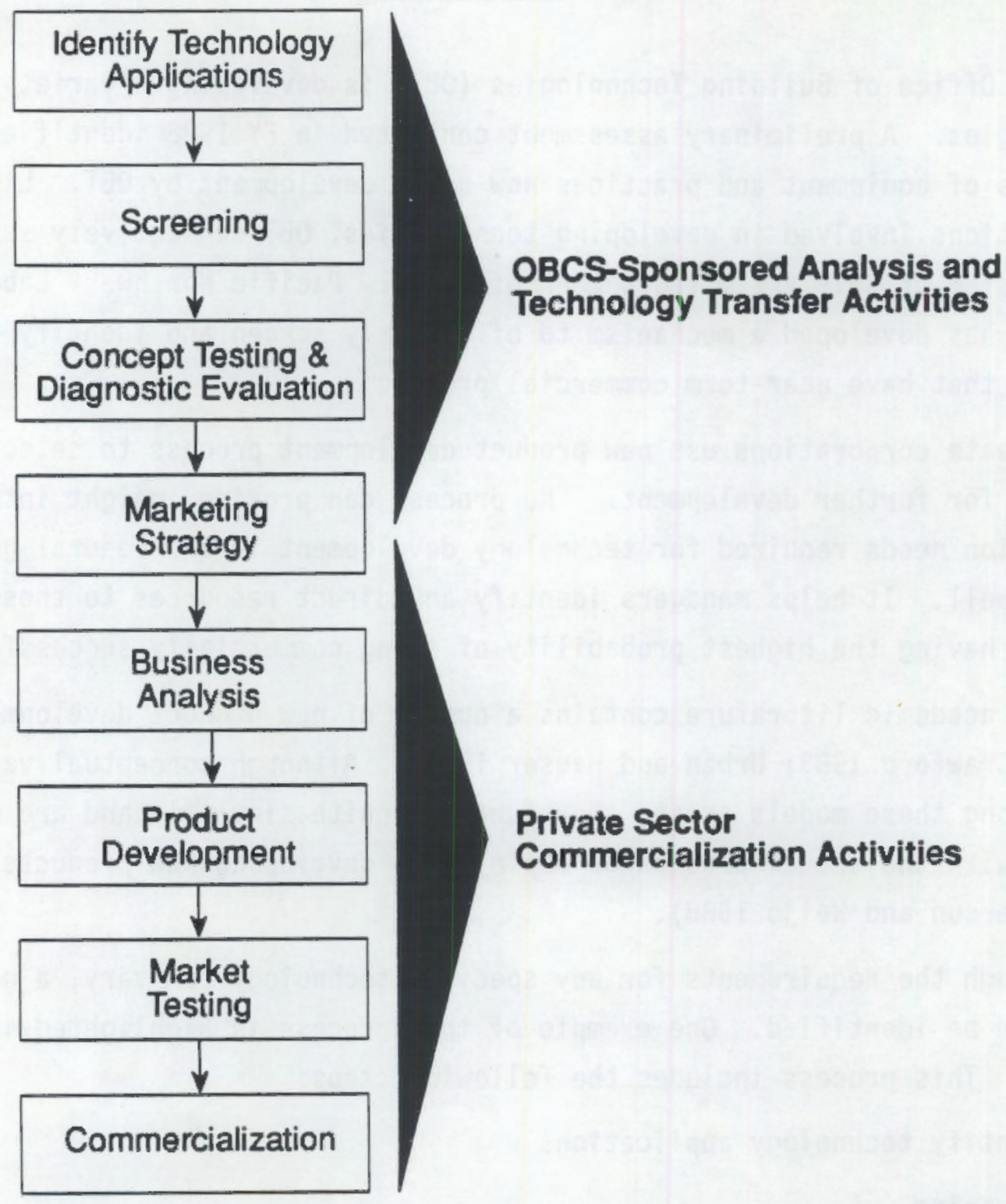

FIGURE 1.1. New Product Development Approach to Technology Commercialization

7. Market testing

8. Commercialization

The technology screening methodology PNL developed for OBT uses a similar framework. It has been used to identify technologies with near-term commercial potential that may require some type of assistance from OBT to be successful in the marketplace. First, a list of equipment and practices under 
development by OBT was developed. Then a survey form was administered to OBT program managers and principal investigators. Information provided by these surveys identified those equipment and practices with near-term opportunities for technology comnercialization. The equipment and practices were also assessed as to whether they might need some type of commercialization assistance from $O B T$.

If followed, this model will assist OBT in its efforts to transfer technology in the early stages of new product development. Manufacturers and trade association may then become the champions of cormercialization during the later stages.

The methodology and the results of its application are described in the remainder of Volume I of this report. Chapter 2.0 describes the methodology employed to screen technologies. Chapter 3.0 identifies technologies that are commercially promising in the near-term. Chapter 4.0 identifies which promising technologies can succeed on their own and which require commercialization assistance. Chapter 5.0 provides final conclusions and recommendations for comercialization strategies. The equipment and practice survey form is presented in Appendix A. Appendix B contains tables that reflect the results of each step in the screening process. Volume II contains the complete results from the equipment and practice survey of program managers and principal investigators. 
, 


\subsection{METHODOLOGY}

An analysis conducted in FY 1988 revealed a lack of information required to effectively screen OBT technologies. A goal of this project was to develop a data base that would provide a consistent set of information across all OBT technologies. This information could then be used to screen OBT technologies for funding priorities and to identify a given technology's progress toward commercialization, assuming the data base was kept current. The methodology used to gather the information and the criteria used to screen the technologies and practices is described below.

\subsection{DATA COLLECTION}

A standardized data collection (survey) form was developed for OBT technologies. This survey form is presented in Appendix A. The OBT Analys is and Technology Transfer Advisory Group provided technical review and comments on the survey form.

The form was designed to simplify the collection of information; it is very short and can be completed in ten minutes. Answers to questions included in this survey generally required either selecting a response range or merely checking an applicable yes/no category. Thus, it encourages the collection of data that provide reasonable estimates to aid identification of the most promising technologies. OBT program managers and principal investigators completed a form for each identified technology.

The survey included questions that would permit analysts to characterize the technology and to determine whether each screening criterion was met. Information collected on the survey inciuded the following:

1. Name and description of the technology

2. Characterization of the technology (equipment/practice)

3. Energy savings characteristics (saves energy directly/indirectly or not at a11)

4. When the technology will be ready for commercialization

5. Whether the technology will require commercialization assistance 
6. Estimated payback period for the technology

7. Market sectors that would benefit from the technology

8. Who is most likely to buy the equipment or use the practice

9. Important commercialization barriers to overcome

10. Energy-related benefits of the technology to customers

11. Non-energy benefits of the technology to customers

12. Conmercial/professional organization interest in the technology The results of the survey can be found in Volume II of this report.

Several important caveats should be carefully kept in mind in assessing the results from the survey instrument. The first is that this survey was administered in 1988; if the survey were conducted today, DOE program managers might respond differently, simply due to increased availability of knowledge about technical and economic performance and potential market success. For example, a program manager might have changed his or her assessment of the technology's simple payback, based upon field tests conducted since 1988. In addition, since the world is a dynamic environment, assessments about potential benefits may have changed from 1988, reflecting different national priorities. Second, the survey instrument, by design, does not ask for regiona1 detail about technologies; instead, the questions are posed at the national level. For example, program managers are asked to identify the simple payback of the technology in a national average sense in broad periods of time. As a consequence, their response should not be construed to imply that this payback would hold in all regions of the country and at all possible energy prices. And third, the results of the survey should not be considered authoritative; if technical staff in industry or in universities were queried instead, to take two examples, it is likely that different responses would result.

\subsection{SCREENING_CRITERIA}

The screening was designed to result in technologies being grouped into one of three distinct categories: 
1. defer commercialization support until later

2. commercialization support needed from OBT

3. technology should succeed without further support.

The categories vary in terms of the level and timing of commercialization assistance required from OBT.

Figure 2.1 depicts the screening model used to place technologies into one of the three categories. Data collected in the survey is used as the needed input for the actual screening.

The first three screening criteria are designed to identify those applications where commercialization support should be deferred until a later date. The first criterion determined whether the technology was ready to be

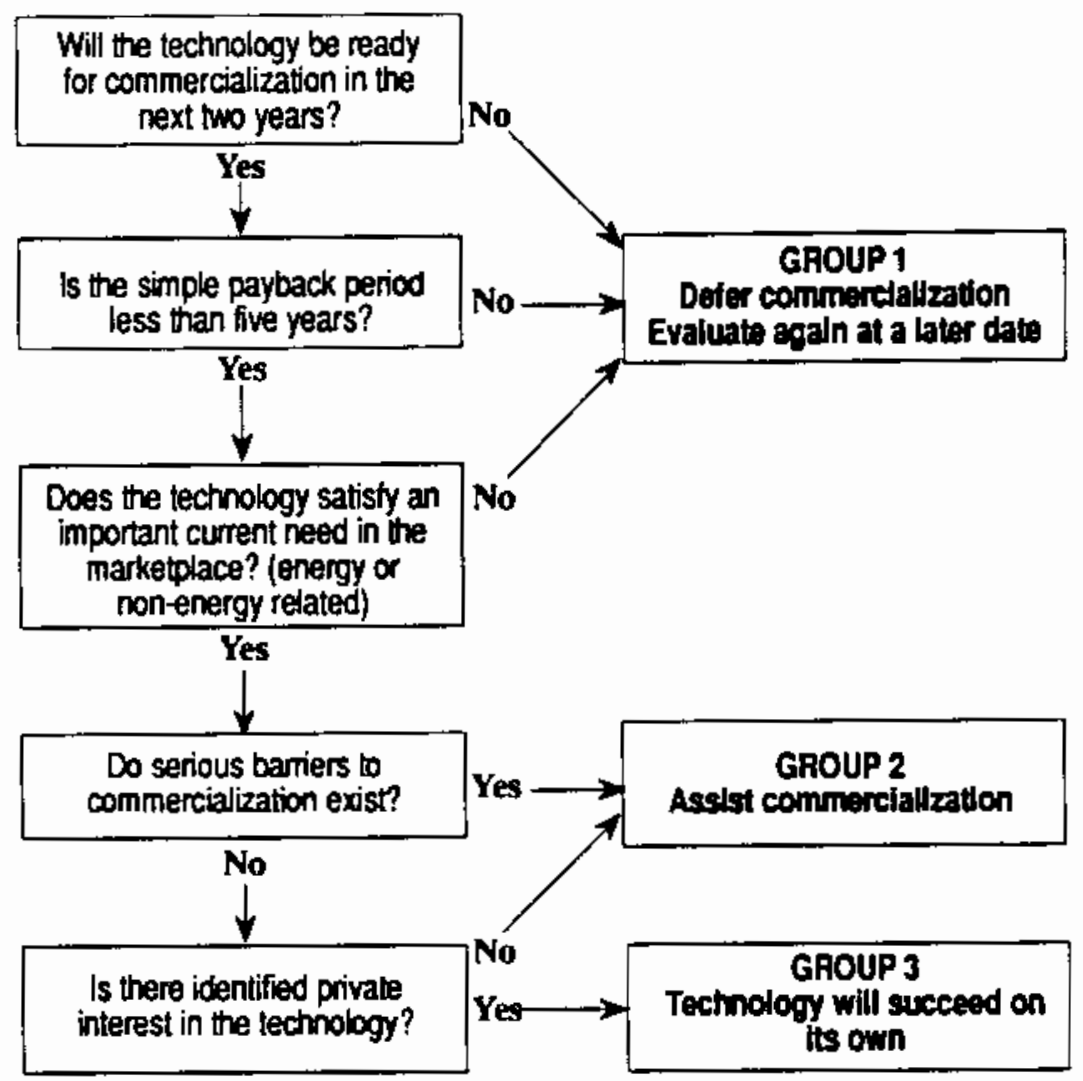

FIGURE 2.1. Technology Screening Mode1 
commercialized within two years. The second criterion identified technologies that have a simple payback period of less than five years (or where payback is not applicable). The third criterion considered whether the technology satisfied a current need in the marketplace. If a technology did not meet each criterion, it was not considered ready for commercialization.

For those technologies that met the above criteria, two additional criteria were applied to determine whether this equipment or practice needed OBT commercialization assistance. The fourth criterion identified those technologies that have major barriers to commercialization. The fifth criterion identified the extent of private interest in a technology. If serious commercialization barriers or lack of private interest were hindering a technology, OBT commercialization assistance was recommended.

Those technologies that met all five screening criteria should succeed on their own without commercialization assistance from OBT. Their progress toward commercialization, however must be carefully monitored. If problems arise which seriously deter commercial success, OBT support would then be advised.

\subsection{DATA ANALYSIS}

The analysis conducted for this study considered over 100 technologies and followed the outlined methodology. Each equipment or practice was screened against the established criteria and placed into one of the three categories described above. 


\subsection{TECHNOLOGIES WITH NEAR-TERM COMMERCIAL PROMISE}

The first three screening criteria were developed to identify OBT technologies that are near-term prospects for commercialization. The results of the first screen are presented below. The information was obtained from the survey administered to OBT program managers and principal investigators.

\subsection{DATE TECHNOLOGY IS READY FOR COMMERC IALIZATION}

At any point in time, only a limited number of technologies are ready to be commercialized. The first screening criterion separates those technologies that are nearly ready for commercialization from those that are not. (See Figure 3.1.) The portfolio of OBT technologies can be grouped into three time perspectives. The first group has finished the basic and applied research stages of development and is now ready for conmercialization assistance. A second group of technologies will be ready for commercial assistance in the next few years. The final group of technologies may not have commercial value for a decade or more. Technologies that will be ready within the next two years will benefit from active technology transfer. Commercial support for long-term, high-risk technologies should be deferred until market entry is closer at hand.

To determine when technologies would be ready for commercialization Question 2 in the survey asked the program managers and principal investigators: "In your opinion, when will this technology be ready to commercialize?" Those technologies that were considered to be ready for commercialization within the next two years are listed in Table 3.1. Since the remaining

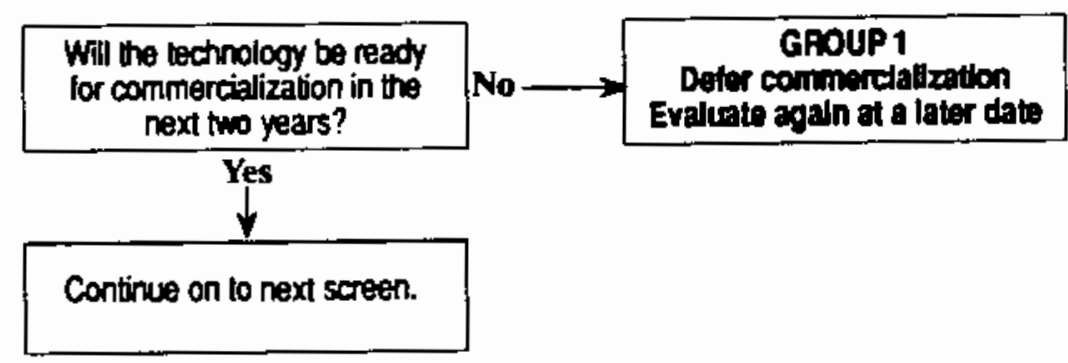

FIGURE 3.1. First Screen in the Technology Screening Model 


\section{IABLE 3,1. OBT Technologies that Will Be Ready for Comercialization Within Two Years}

\section{Ready Now}

Building Equipment Division

Building Services Division

Building Systems Division

Shared Savings

Urban Heat is lands
Optimized Ground Coupled Heat Pump

Diagnostic Protocols and Analys is Methods

Acoust tc Testing of Attic Insulation

Aerated Autoclave Insulation

Commercial Standards

Corrosiveness of Insulation

Field Thermal Performance Methodology

Foundation Design Tools Including Handbooks

$\mathrm{HVAC} / \mathrm{L}$ ight ing Interact Ions

Large Scale Climate Simulator (LSCS)

Loose Fill Attic Insulation Settling

Ma intenance and Upgrading of DOE-2

Multi-Zonal Infiltrat lon and Ventilation Measurement

PROPOR

Radiant Barrier Systems

Roof Research Center - A National User Facility

Roof Thermal Research Apparatus (RTRA)

Small offlce Butlding Handbook

Superlite

Window 3.1 Computer Program

\section{$1-2$ Years}

Solid Fuel Appliance Heasurement Hethods

Analytical Tools

Btu Meter

Core Comerc1sl Daylighting

Dlagnost ic Tool Development

Energy Track ing Systen

Friction Reduction Additives

Integrated Utility Planning Processes

Mult if amily Audit Handbook

Radiant Barrier Climatic Guide

Radiant Barrier Modeling

Strategles for Energing I ssues

Technical Assessment and Market Penetration

Advanced Durable Low-E Costings

Advanced Leakage Techn iques

Advanced Residential Ventilation Systens

High-R Windows

Mathematical Modeling of Indoor Air Quality Molsture Guidelines for Residences

Perfluorocarbon Tracer System

Roof Surface Treatment Guldelines

Sick Butlding Syndrome Protocol

Stmplifted Themal Analys is of Roofs (STAR)

Thermal Bridges Design Catalog 
technologies did not pass the first screening criterion, they were excluded from further screening. All the technologies are listed in Appendix B, Table B.1. They have been grouped into five categories based on the number of years before the technology will be ready. for commercialization.

Forty-six technologies passed through the first screen. Of those 22, are ready for commercialization now and 24 will be ready for commercialization in one to two years.

\subsection{SIMPLE PAYBACK PERIOD}

The 46 technologies remaining after the first screen were run through the second screen--payback criterion. (See Figure 3.2.) Previous energy research has found that consumers typically demand a rapid payback period for energy conservation investments. Ruderman, Levine and McMahon (1987) report discount rates of between $20 \%$ and $200 \%$ for appliance conservation investments. This suggests that payback periods for conservation investments should ideally be under two years and definitely under five years. Ruderman, Levine and McMahon provide several explanations for consumer under-investment in efficiency:

"We conclude that the market for energy efficiency is not performing we11. He propose and discuss several explanations for the under-investment in efficiency: 1) lack of information about the costs and benefits of energy efficiency; 2) difficulty in obtaining the additional capital to purchase more expensive energy-efficiency appliances; 3) expected savings too small to be of interest to purchasers; 4) prevalence of third-party purchasers; 5) the loading of highly efficient equipment with other features or a scarcity of highly-efficient equipment; 6) long manufacturing lead time; and 7) marketing strategies that may discourage the purchase of more efficient products."

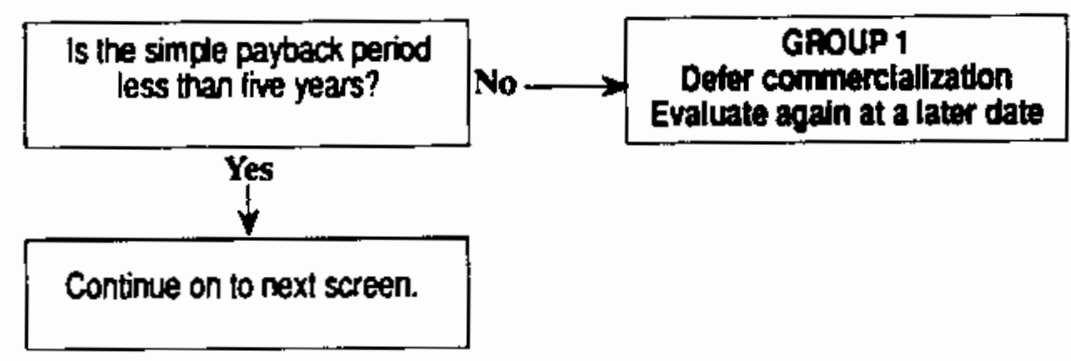

FIGURE 3.2. Second Screen in the Technology Screening Model 
The basis for the screening came from responses to Question 4 in the survey: "Please estimate this technology's simple payback period to the customer." Simple payback period was defined as the length of time needed to recover the customer's capital investment in a technology. Table 3.21 ists the technologies that are listed in Table 3.1 and that are considered to have payback periods of five years or less. Technologies where payback periods are not applicable are also listed. This "not applicable" category of technologies primarily includes research tools, software, procedures, and mathematica] models which do not directly save energy.

After this screen, 44 technologies remained. The simple payback periods for all of the technologies in the study are shown in Appendix B, Table B.2.

\subsection{CURRENT NEEDS IN THE MARKETPLACE}

The third screening criterion focuses on market needs. (See Figure 3.3.) Like many DOE programs, OBT faces an interesting dilemma. It must support a long-term energy research program in an arena of volatile energy prices. Conservation does not sell when oil prices are $\$ 12$ to $\$ 18$ per barrel. However, at any given time, other issues are important to the energy industry. Thus, OBT must identify and promote those technologies that provide solutions to current problems. As the importance of problems within the energy industry changes, the mix of technologies receiving commercialization support must change. Thus, the near-term technology transfer effort must always be opportunistic in its focus.

The market needs considered are of two types: energy-related and nonenergy-related. In the survey, respondents were asked, "What do you think are the energy-related benefits of this equipment or practice to customers?" They were also asked to report what they thought were the non-energy benefits of this technology (Questions 7 and 8 ). The energy-related benefits listed in the survey were:

- reduces energy bills

- reduces usage of a scarce fuet

- reduces peak energy loads 


\section{TABLE 3.2. OBT Technologies that Have Simple Payback Periods of Five Years or Less and Will Be Ready for Commercialization Within Two Years (a)}

Building Equipment Division

Not Applicable

Solid Fuel Appliance Measurement Methods

\section{$3-5$ Years}

Opt imized Ground Coupled Heat Pump

Building Services Divișion

\section{Analytical Tools}

Diagnost ic Tool Development

Energy Tracking System

Friction Reduction Additives

Integrated Ut 1 lity Planning Processes

Radiant Barrier Modeling

Radiant Barrier Climatic Guide

Strategies for Emerging Issues

Technology Assessment and Market Penetration
Btu

Core Commerctal Daylighting
Diagnost ic Protocols and Ana lys is Methods

Mult if amily Audit Handbook

Shared Savings

Urban Heat Is lands

Building Systems Division

Acoust ic Testing of Attic Insulation

Advanced Leakage Techniques

Corrosiveness of Insulation

Maintenance and Upgrading of DOE-2

Mathematical Modeling of Indoor Air Quality

Moisture Guidelines for Residences

Multi-Zonal Infiltration and Vent llation Measurement

Perf luorocarbon Tracer System

Sick Bujlding Syndrame Protocol

Window 3.1 Computer Program
Advanced Residential Ventilation Systems

Conmercial Standards

Foundation Design Tools. Including Handbooks

Small office Building Handbook

Superlite

(a) No response was received for either the PROPOR or the Simplified Thermal Analys is of Roofs (STAR) technologies
Advanced Durable Low-E Coatings

Aerated Autoclaved Concrete

Field Thermal Performance Methodology High-R Uindows

HVAC/L lght ing Interact ions

Roof Research Center - A Hational User Facility

Roof Therma 1 Research Apparatus (RTRA)

Thermal Bridges Design Catalog 


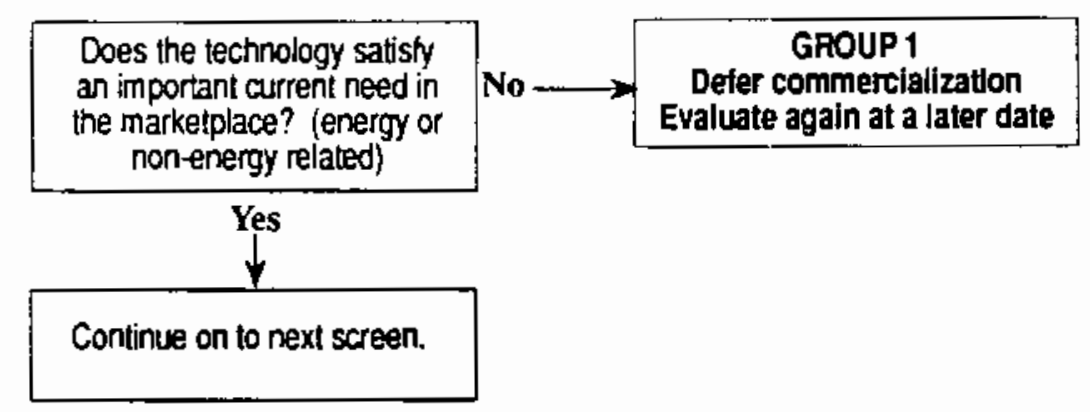

FIGURE 3.3. Third Screen in the Technology Screening Model

- creates a backup fuel capability.

The non-energy-related benefits listed include:

- provides healthier indoor air environment

- increases thermal comfort

- increases visua] comfort

- reduces noise/sound levels

- enhances building attractiveness

- eases building operation \&aintenance

- improves system reliability

- reduces first cost for product.

Either the chosen energy-related or non-energy-related benefit was allowed to serve as an indication that the technology met a current market need. For this screening, the energy-related benefit that was chosen was "reduces peak energy loads" and the non-energy-related benefit was "provides healthier indoor air environment." Within the two market need categories, any of the above listed criteria could be chosen to replace the criteria used. The criteria chosen should reflect the market needs of that time period.

of the 44 technologies listed previously in Table 3.2, 18 could reduce peak energy loads. These technologies are listed in Table 3.3. (The energy benefits of all of the technologies are listed in Appendix B, Table B.3.) 
IABLE 3.3. OBT Technologies That Reduce Peak Energy Usage, Have Simple Payback Periods of Five Years or Less, and Will Be Ready for Commercialization Within Two Years

Building Equipment Division

Optimized Ground Coupled Heat Pump

\section{Building Services Division}

Analytical Tools

Core Comercial Daylighting

Diagnostic Protocols and Analysis Methods

Friction Reduction Additives

Integrated Utility Planning Processes

Radiant Barrier Climatic Guide

Shared Savings

Strategies for Emerging Issues

Technology Assessment and Market Penetration

Urban Heat Islands

\section{Building Systems Division}

Advanced Durable Low-E Coatings

Aerated Autoclaved Concrete

Commercial Standards

HVAC/Lighting Interactions

Roof Surface Treatment Guidelines

Small Office Building Handbook

Superlite

The non-energy-related market criterion used to screen OBT technologies "provides a healthier indoor air environment." of the 44 technologies remaining after the first two screens (see Table 3.2), 8 provided heal thier indoor air environments. These technologies are listed in Table 3.4. (The nonenergy benefits of all the technologies are listed in Appendix B, Table B.4.) These 8 technologies were different from the $1 B$ technologies that offered to reduce peak energy usage. Therefore, 26 technologies showed indications of meeting a current market need in addition to being ready for commercialization within two years and having simple payback periods of five years or less. 
TABLE 3.4. OBT Technologies That Provide Healthier Indoor Air Environments, Have Simple Payback Periods of Five Years or Less, and will be Ready for Commercialization Within Two Years $(a)$

\section{Building Systems Division}

Advanced Leakage Techniques

Advanced Residential Ventilation Systems

Foundation Design Tools Including Handbooks

Mathematical Modeling of Indoor Air Quality

Moisture Guidel ines for Residences

Multi-Zonal Infiltration and Ventilation Measurement

Perfluorocarbon Tracer System

Sick Building Syndrome Protocol

(a) None of the technologies in the Building Services Division or the Building Equipment Division met all three criteria.

\subsection{IDENTIFICATION OF NEAR-TERM PROMISING TECHNOLOGIES}

Technologies that are commercially promising in the near-term are those that meet all three of the above established criteria: 1) they are ready for conmercialization in two years, 2) have a simple payback period of five years or less, and 3) satisfy an important current need in the marketplace (both energy- and non-energy-related.) Table 3.5 summarizes the technologies that met these criteria. 
IABLE 3.5. OBT Technologies That Are Commercially Promising in the Near-Term

Building Equipment Division

Optimized Ground Coupled Heat Pump

Building Services Division

Analytical Tools

Core Cormercial Daylighting

Diagnostic Protocols and Analysis Methods

Friction Reduction Additives

Integrated Utility Planning Processes

Radiant Barrier Climatic Guide

Shared Savings

Strategies for Emerging Issues

Technology Assessment and Market Penetration

Urban Heat Islands

\section{Building Systems Division}

Advanced Durable Low-E Coatings

Advanced Leakage Techniques

Advanced Residential Ventilation Systems

Aerated Autoclaved Concrete

Commercial Standards

Foundation Design Tools Including Handbooks

HVAC/Lighting Interactions

Mathematical Modeling of Indoor Air Quality

Moisture Guidel ines for Residences

Multi-Zonal Infiltration and Ventilation Measurement

Perfluorocarbon Tracer System

Roof Surface Treatment Guidelines

Sick Building Syndrome Protocol

Small Office Building Handbook

Superlite 



\subsection{TECHNOLOGIES THAT WILL SUCCEED ON THEIR OWN}

Not al1 promising technologies will require commercialization assistance. In those instances where few conmercial barriers exist or where private industry has been involved in the development process, no additional resources are required to support commercialization. If commercialization barriers do exist and/or no private sector interest is identified, additional resources must be allocated to support the commercialization of the technologies. The fourth and fifth screening criterion will separate the remaining technologies into these categories. Both of these criteria are discussed below.

\subsection{COMMERCIALIZZTION BARRIERS}

At any point in time, a variety of factors can impinge on or interfere with the commercial success of a technology. Question 6 in the survey asked the program managers and principal investigators, "What do you think are the important commercialization barriers to overcome?" The program managers and principal investigators were asked to check all of the barriers that pertained to the comnercialization of the technology. The barriers are listed below in Table 4.1. A distinction was made between those that will be relatively easy to overcome and those that will not.

\section{IABLE 4.1. Conmercialization Barriers}

\section{Simplest Barriers}

Lack of awareness about equipment/practice Lack of understanding about equipment/practice Large number of decision makers involved Reliability concerns about technology

\section{Potentially Serious Barriers}

Environmental concerns

Conflicts with existing building codes

Legal and regulatory difficulties

Unavailability of financing

High perceived risk because new/different

High first cost for technology 
If it had one or more potentially serious barriers, the technology was determined to need OBT technology transfer assistance. (See Figure 4.1.) The remaining technologies were considered technologies that could survive without OBT help and were evaluated in the final screening. Of the 26 technologies with near-term comercial promise (shown in Table 3.5) 19 had one or more barriers that were classified as potentially serious. These technologies are shown in Table 4.2. The barriers identified for all of the technologies are shown in Appendix B, Table B.5.

\subsection{PRIVATE SECTOR INTEREST IN PROMISING TECHNOLOGIES}

Even if few barriers exist, the likelihood of commercial success will be 1 imited if there is no private sector interest in a technology. The most successful commercialization strategy includes involvement by the private sector at the very earliest stages of research and development.

The OBT technologies were analyzed to determine where significant private sector or trade association interest had been identified. (See Figure 4.2.) Question 9 in the survey asked the program managers and principa 7 investigators, "To your knowledge, have any commercial or professional organizations indicated an interest in either licensing or using this equipment or practice?" Answers to this question provided input for the fifth screening criterion. Only those seven technologies that have no serious barriers went to this screen. If the program managers or principal investigators answered affirmatively, the technology was considered to be on its own, not needing any commercialization assistance from OBT.

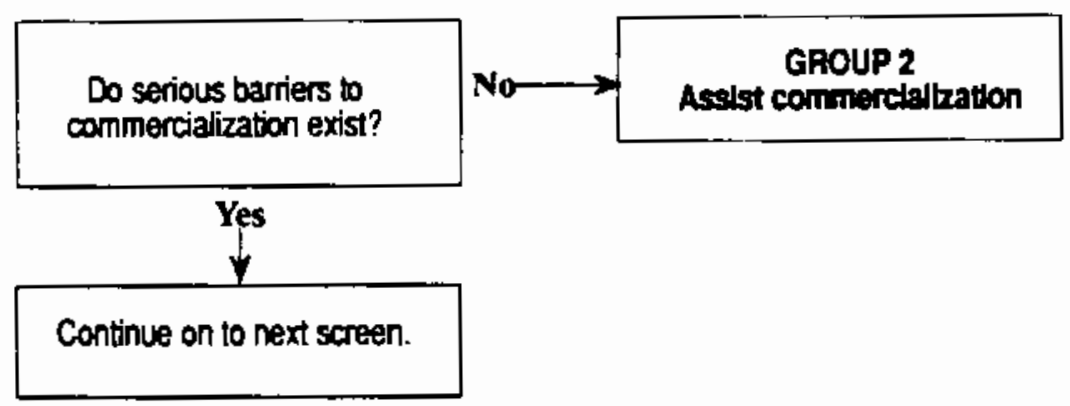

FIGURE 4.1. Fourth Screen in the Technology Screening Model 
IABLE 4.2. Technologies with Serious Barriers to Commercialization

Building Equipment Division

Optimized Ground Coupled Heat Pump

Building Services Division

Core Commercial Daylighting

Diagnostic Protocois and Analysis Methods

Friction Reduction Additives

Shared Savings

Strategies for Emerging Issues

Technology Assessment and Market Penetration

Urban Heat Islands

\section{Building Systems Division}

Advanced Durable Low-E Coatings

Advanced Leakage Techniques

Advanced Residential Ventilation Systems

Aerated Autoclaved Concrete

Commercial Standards

HVAC/Lighting Interactions

Mathematical Modeling of Indoor Air Quality

Moisture Guide? ines for Residences

Multi-Zonal Infiltration and Ventilation Measurement

Simall office Building Handbook

Superitite

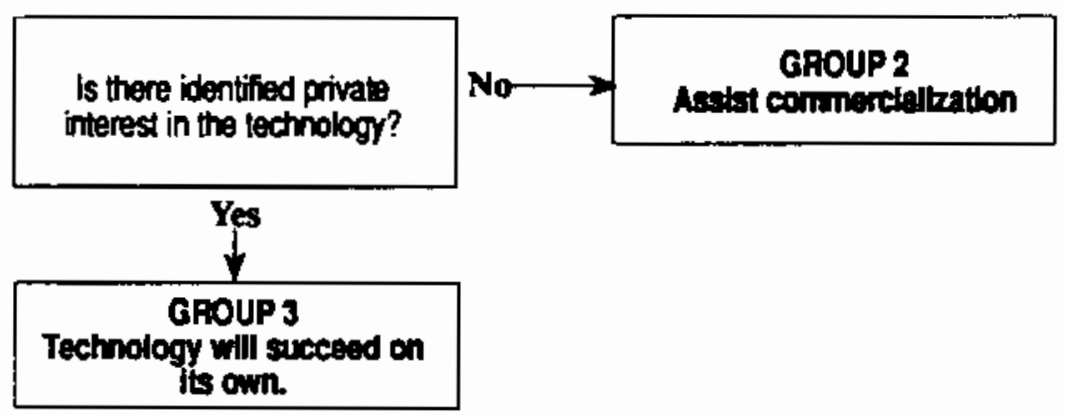

FIGURE_4.2. Fifth Screen in the Technology Screening Mode] 
(The commercial or professional organizations indicating an interest in either licensing or using the equipment or practice are shown in Appendix $B$, Table B.6, for interest and future tracking of the technology.) The remaining four technologies (listed in Table 4.3) have near-term commercial potentiat, but have serious barriers and no interested backers.

\subsection{SUMMARY}

The 23 technologies listed in Table 4.4 are the technologies that warrant immediate commercialization support. (Table 4.4 is the union of Tables 4.2 and 4.3.) The technologies that are not included in this list have either already gained support through private industry, do not face serious barriers to implementation, or are not ready for commercialization.

The technologies requiring assistance have promising commercialization prospects, but without OBT support will most likely remain in the laboratories and not gain widespread market use. A few of the technologies that did not indicate having private support, actually have already received other DOE commercialization support. The following technologies have already been selected as projects needing government aid in commercializing: optimized ground coupled heat pump, shared savings, commercial standards, and sma11 office building handbook.

Three technologies were classified as able to survive on their own. They are analytical tools; integrated utility planning processes; and foundation design tools, including handbooks.

IABLE 4.3. Technologies in which There is No Private Interest in Licensing or Using

Building Services Division

Radiant Barrier Climatic Guide

Building Systems Division

Perfluorocarbon Tracer System

Roof Surface Treatment Guidelines

Sick Building Syndrome Protocol 
TABLE 4.4. Technologies Requiring Assistance

Building Equipment Division

Optimized Ground Coupled Heat Pump

Building Services Division

Core Commercial Daylighting

Diagnostic Protocols and Analysis Methods

Friction Reduction Additives

Radiant Barrier Climatic Guide

Shared Savings

Strategies for Emerging Issues

Technology Assessment and Market Penetration

Urban Heat Is lands

Building Systems Division

Advanced Durable Low-E Coatings

Advanced Leakage Techniques

Advanced Residential Ventilation Systems

Aerated Autoclaved Concrete

Commercial Standards

HVAC/Lighting Interactions

Mathematical Modeling of Indoor Air Quality

Moisture Guidelines for Residences

Multi-Zonal Infiltration and Ventilation Measurement

Perfluorocarbon Tracer System

Roof Surface Treatment Guidelines

Sick Building Syndrome Protocol

Small office Building Handbook

Superlite 



\subsection{CONCLUSIONS AND RECOMMENDATIONS}

Use of the screening methodology reduced the number of technologies which should receive attention from over 100 to a more manageable number of 23 . of these 23, 4 are already receiving substantial aid from DOE.

The screening process should not be used as a one-time process, but rather should be constantly reviewed. The review and screening process helps to identify those technologies that are currently the most promising commercialization prospects; however, the market changes rapidly and, consequently, so do its needs. New technologies emerge, some previously supported projects become championed by industry, others become obsolete as market situations change, and still others that were previously excluded become market-ready.

Although this methodology was designed specifically for OBT technologies, it could easily be adapted to support other DOE project/technology funding decisions. The method provides a systematic way to prioritize commercialization opportunities within a limited budget framework. 



\subsection{REFERENCES}

Crawford, C. M. 1983. New Products Management. Richard D. Irwin, Inc., Homewood, Illinois.

Roberson, B. F., and R. 0. Weijo. 1988. "Using Market Research to Convert Federal Technology Into Marketable Products." Journal of Technology Transfer. Vol. 13, No. I.

Ruderman, H., M. D. Levine and J. E. McMahon. 1987. "The Behavior of the Market for Energy Efficiency in Residential Appliances Including Heating and Cooling Equipment." The Energy Journal 8(1):101-124.

Urban, G. L., and J. R. Hauser. 1980. Design and Marketing of New Products. Prentice-Hali, Englewood Cliffs, New Jersey. 



\section{APPENDIX A}

\section{EQUIPMENT AND PRACTICE FORM}




\title{
APPENDIX A
}

\section{EQUIPMENT AND PRACTICE FORM}

\begin{abstract}
Appendix A consists of the Equipment and Practice Form. This is a standardized data collection form that was given to OBT program managers and principal investigators. The form was to be completed for each identified technology. Answers to the questions permitted characterization of the technology and determination of whether each screening criterion was met. The results of the survey can be found in Volume II of this study.
\end{abstract}




\section{EOUIPMENT AND PRACTICE FORM}

Instructions: Please complete a separate form for each unique equipment or practice being developed or studied in your program. Please complete forms for items even if they do not save energy.

Project Identification:

(a) Program:

(b) Subprogram:

(c) Key Activity:

(d) Project:

1. Equipment or Practice:

a) Name of equipment or practice:

b) Description of equipment or practice:

c) Would you characterize this technology as primarily an equipment (i.e., hardware) or a practice (i.e., software or knowledge-based): (Please check only one)

Equipment

—- Practice

d) Describe the energy characteristics of this equipment or practice (please select one):

Saves energy directly -

$$
\begin{aligned}
& \text { Estimate the savings of this } \\
& \text { technology over state-of-the- } \\
& \text { art equipment/practices } \\
& \% \text { savings (to the } \\
& \text { nearest } 5 \% \text { ). }
\end{aligned}
$$

Indirectly saves energy by solving a problem created by the installation of energy-saving technologies (e.g., indoor air pollution). 
Does not save energy (e.g., equipment developed to study the energy characteristics of a building.

2. In your opinion, when will this technology be ready to comnercialize? (please select one)

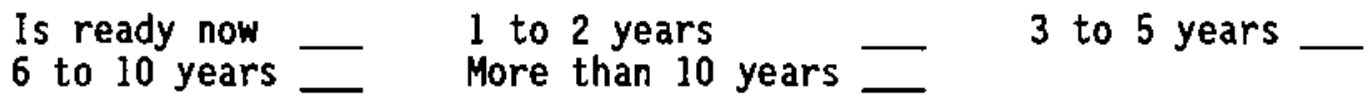

3. In your opinion, will this equipment or practice require conmercialization assistance from $O B T$ for it to succeed in the marketplace? (select one)

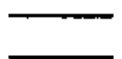
Will require $O B T$ assistance
Will succeed on its own

4. Please estimate this technology's simple payback period to the customer. (Note: The simple payback period is the length of time it takes to recover the customer's capital investment in a technology. Thus, if $\$ 100$ is invested and provides an average savings of $\$ 25 /$ year, the payback is four years.)
0 to 2 years
3 to 5 years
6 to 10 years
More than 10 years -
Not applicable

5. Market/Applications for Equipment or Practice:

a) Which market sectors are most likely to benefit from the use of this equipment or practice? (please check all that apply)

\section{New Retrofit/Replacement \\ Application}

Residential Buildings

Single-family

Multi-family

Manufactured home

Commercial Buildings

Less than $10,000 \mathrm{sq} . \mathrm{ft}$.

10,000-100,000 sq.ft.

Greater than $100,000 \mathrm{sq} . \mathrm{ft}$.

Communities

Other (please list)

b) Who is most likely to buy the product or use the practice?

(please check all that apply)

Single-family homeowners

- Multi-family homeowners

- Commercial building owners or managers

\section{A. 3}


Public or government building managers

- Non-profit or government building managers

- Builders, contractors or installers

- Architects or engineers

- Renters or tenants

- Energy utilities

- Industrial manufacturers

- Government officials and regulators

_ Other (please describe)

6. What do you think are the important commercialization barriers to overcome? (please check all that apply)

- Lack of awareness about equipment/practice

- Lack of understanding about equip./practice

- Large number of decision makers involved

- Environmenta] concerns

- Conflicts with existing building codes

- Legal and regulatory difficulties

- Unavailability of financing

- High perceived risk because new/different

- High first cost for technology

- Reliability concerns about technology

- Other (please specify)

7. What do you think are the energy-related benefits of this equipment or practice to customers? (please check all that apply)

- Reduces energy bills

- Reduces usage of scarce fuel

- Reduces peak energy loads

- Creates a backup fuel capability

- Other (please specify)

8. What do you think are the non-energy benefits of this equipment or practice to customers? (please check all that apply)

Heal thier indoor air environment

- Greater thermal comfort

- Greater visual comfort

- Reduced noise/sound levels

- Enhanced buijding attractiveness

- Eases building operation \& maintenance

- Improves system reliability

- Reduced first cost for product

- Other (please specify) 
9. Commercial or Professional Interest in Equipment or Practice

a) To your knowledge, have any commercial or professional organizations indicated an interest in either licensing or using this equipment or practice?

- Yes

b) If yes, please list who they are:

10. Name and Telephone Number of Person Completing Form

Name of person completing form:

Telephone number (including area code): 

APPENDIX B

RESULTS OF TECHNOLOGY SCREENING 
APPENDIX B

\section{RESULTS OF TECHNOLOGY SCREENING}

Data from the Equipment and Practice Form were used as the needed input for the screening. The screening was designed to group technologies into one of three distinct categories:

1. defer commercialization support until later

2. commercialization support needed from OBT

3. technology should succeed without further support.

The categories vary in terms of the level and timing of conmercialization assistance required from OBT.

Appendix $B$ consists of tables representing the results of each step in the screening process. The results are broken down by each division within OBT. There are 29 technologies in the Building Equipment Division, 29 technologies in the Building Services Division, and 46 technologies in the Building Systems Division. 
IABLE B.1. Time Needed to Ready Technology for Commercialization

\section{BUILDIMG EQUIPMENT DIVISION}

\section{TECHNOLOGY IS READY NOW:}

OPTIMIZED GROUND COUPLED HEAT PUMP

TECHNOLOGY WILL BE READY IN 1 TO 2 YEARS:

SOLID FUEL APPLIANCE MEASUREMENT METHODS

TECHNOLOGY WILL BE READY IN 3 TO 5 YEARS:

ADVANCED CONDENSING HEAT EXCHANGERS

ADVANCED LIGHTING CONTROLS

COMMERC IAL AND RESIDENTIAL ZONING

CONSERVATION MEASURES THROUGH FORCED-AIR DISTRIBUTION

DIRECT VENT TECHNOLOGY

DYNAMIC LIGHTING DESIGN

IN VITRO DIAGNOSTICS

ISOTOPICALLY ENRICHED FLUORESCENT

LOW-FIRING RATE OIL BURNER TECHNOLOGY

PERFORMANCE CONTROL STRATEGIES

VARIABLE-SPEED COMPRESSORS \& FANS

WOOD COMBUSTION SYSTEMS

TECHNOLOGY WILL BE READY IN 6 TO 10 YEARS:

ABSORPTION FLUIDS

ADVANCED CONCEPT ABSORPTION HEAT PUMP

ADVANCED INSULATION

ADVANCED PHOSPHOR MATERIALS

CERAMIC FLUID PUMPS

DESICCANT/HYBRID COOLING SYSTEMS

EJECTOR COUPLED HP CYCLE

ELECTRODELESS HIGH-INTENSITY DISCHARGE LIGHT

FIFTEEN-TON BRAUN LINEAR ENGINE HP.

FUEL-OIL ATOMIZATION/COMBUSTION

HERMETIC COMPRESSOR SEALS

INCANDESCENT REPLACEMENT BY H.I.D.

STIRLING/RANK. DIA. COUPLED HP.

SURFACE WAVE FLUORESCENT

TECHNOLOGY WILL BE READY IN MORE THAN 10 YEARS:

NONAZEOTROPIC REFRIGERANT MIXTURES 
TABLE B.1. (contd)

BUILDING SERVICES DIVISION

TECHNOLOGY IS READY NOW:

DIAGNOSTIC PROTOCOLS AND ANALYSIS METHODS

SHARED SAVINGS

URBAN HEAT ISLANDS

TECHNOLOGY WILL BE READY IN 1 TO 2 YEARS:

ANALYTICAL TOOLS

BTU METER

CORE COMMERCIAL DAYLIGHTING

DIAGNOSTIC TOOL DEVELOPMENT

ENERGY TRACKING SYSTEM

FRICTION REDUCTION ADDITIVES

INTEGRATED UTILITY PLANNING PROCESSES

MULTIFAMILY AUDIT HANDBOOK

RADIANT BARRIER CLIMATIC GUIDE

RADIANT BARRIER MODELING

STRATEGIES FOR EMERGING ISSUES

TECHNOLOGY ASSESSMENT AND MARKET PENETRATION

TECHNOLOGY WILL BE READY IN 3 TO 5 YEARS:

ABSORPTION CHILLER

ACOUSTIC LEAK DETECTION SYSTEM

ADVANCED RANKINE CYCLE HEAT PUMP

COMMERCIAL BUILDING RETROFIT PROCEDURES

HEAT PUMP (QUASI OPEN CYCLE)

MOBILE HOME RETROFIT PROCEDURES

MULTIFAMILY RETROFIT PROCEDURES

OPERATING AND MAINTENANCE PROCEDURES

PUBLIC HOUSING RETROFIT PROCEDURES

VACUUM STEAM RADIATORS

TECHNOLOGY WILL BE READY IN 6 TO 10 YEARS:

ADVANCED DUCT SEALING TECHNIQUES

DOWN-HOLE HEAT EXCHANGER

ICE SLURRY EVAPORATOR

NON-METALLIC PIPING SYSTEM

\section{BUILDING SYSTEES DIVISION}

NON-RESPONSE TO QUESTION 2:

COMPOSITE/PRE-BUILT WALL SYSTEMS

FOAM AGING AND R-VALUE PREDICTION

MOISTURE IMPACTS ON MATERIALS

RADIATIVE HEAT TRANSFER

SWITCHABLE E MATERIALS

THERMAL CONDUCTIVITY MEASUREMENTS OVER RANGE OF ENVIRONMENTAL TEMPS. 
TABLE B.1. (contd)

TECHNOLOGY IS READY NOW:

ACOUSTIC TESTING OF ATTIC INSULATION

AERATED AUTOCLAVED CONCRETE

COMMERCIAL STANDARDS

CORROSIVENESS OF INSULATION

FIELD THERMAL PERFORMANCE METHODOLOGY

FOUNDATION DESIGN TOOLS INCLUDING HANDBOOKS

HVAC/LIGHTING INTERACTIONS

LARGE SCALE CLIMATE SIMULATOR (LSCS)

LOOSE FILL ATTIC INSULATION SETTLING

MAINTENANCE AND UPGRADING OF DOE-2

MULTI-ZONAL INFILTRATION AND VENTILATION MEASUREMENT

PROPOR

RADIANT BARRIER SYSTEMS

ROOF RESEARCH CENTER - A NATIONAL USER FACILITY

ROOF THERMAL RESEARCH APPARATUS (RTRA)

SMALL OFFICE BUILDING HANDBOOK

SUPERLITE

WINDOW 3.I COMPUTER PROGRAM

TECHNOLOGY WILL BE READY IN I TO 2 YEARS:

ADVANCED DURABLE LOW-E COATINGS

ADVANCED LEAKAGE TECHNIQUES

ADVANCED RESIDENTIAL VENTILATION SYSTEMS

HIGH-R WINDOWS

MATHEMATICAL MODELING OF INDOOR AIR QUALITY

MOISTURE GUIDELINES FOR RESIDENCES

PERFLUOROCARBON TRACER SYSTEM

ROOF SURFACE TREATMENT GUIDELINES

SICK BUILDING SYNDROME PROTOCOL

SIMPLIFIED THERMAL ANALYSIS OF ROOFS (STAR)

THERMAL BRIDGES DESIGN CATALOG

TECHNOLOGY WILL BE READY IN 3 TO 5 YEARS:

ADVANCED DESIGN TOOLS

ALTERNATIVE CFC-BASED INSULATIONS IN WALL AND FOUNDATION SYSTEMS

IMBEDDED MEAT FLUX TRANSDUCERS

NON-INTRUSIVE MOISTURE PROBE

PASSIVE SAMPLER OF VOLATILE ORGANIC COMPOUNDS (VOC)

TECHNOLOGY WILL BE READY IN 6 TO IO YEARS:

ENERGY KERNEL SYSTEM

MANUFACTURED MOUSING INSULATION

MOISTURE MEASUREMENT METHODOLOGY

POWDER-FILLED EVACUATED INSULATION PANELS

SUBSTITUTE FOAMING AGENTS FOR INSULATION

TECHNOLOGY WILL BE READY IN MORE THAN IO YEARS:

VARIABLE R MATERIALS 
TABLE_B.2. Simple Payback Period for All Technologies

BUILDING EQUIPIENT DIVISION

NO RESPONSE TO QUESTION 4:

SURFACE WAVE FLUORESCENT

NON-APPLICABLE:

DYNAMIC LIGHTING DESIGN

SOLID FUEL APPLIANCE MEASUREMENT METHODS

0 TO 2 YEAR SIMPLE PAYBACK PERIOD:

ADVANCED PHOSPHOR MATERIALS

ADVANCED CONDENSING HEAT EXCHANGERS

COMMERCIAL AND RESIDENTIAL ZONING

DIRECT VENT TECHNOLOGY

IN VITRO DIAGNOSTICS

ISOTOPICALLY ENRICHED FLUORESCENT

PERFORMANCE CONTROL STRATEGIES

3 TO 5 YEAR SIMPLE PAYBACK PERIOD:

ABSORPTION FLUIDS

ADVANCED CONCEPT ABSORPTION HEAT PUMP

ADVANCED INSULATION

ADVANCED LIGHTING CONTROLS

ELECTRODELESS HIGH-INTENSITY DISCHARGE LIGHT

INCANDESCENT REPLACEMENT BY H.I.D.

CERAMIC FLUID PUMPS

CONSERVATION MEASURES THROUGH FORCED-AIR DISTRIBUTION

DESICCANT/HYBRID COOLING SYSTEMS

EJECTOR COUPLED HP CYCLE

FIFTEEN-TON BRAUN LINEAR ENGINE HP.

FUEL-OIL ATOMIZATION/COMBUSTION

HERMETIC COMPRESSOR SEALS

LOW-FIRING RATE OIL BURNER TECHNOLOGY

OPTIMIZED GROUND COUPLED HEAT PUMP

STIRLING/RANK. DIA. COUPLED HP.

WOOD COMBUSTION SYSTEMS

6 TO 10 YEAR SIMPLE PAYBACK PERIOD:

NONAZEOTROPIC REFRIGERANT MIXTURES

VARIABLE-SPEED COMPRESSORS \& FANS

\section{BUILDING SERVICES DIYISIOH}

NON-APPLICABLE:

ANALYTICAL TOOLS

DIAGNOSTIC TOOL DEVELOPMENT

ENERGY TRACKING SYSTEM

FRICTION REDUCTION ADOITIVES

INTEGRATED UTILITY PLANNING PROCESSES

RADIANT BARRIER CLIMATIC GUIDE

RAOIANT BARRIER MOOELING 
TABLE B.2. (contd)

STRATEGIES FOR EMERGING ISSUES

TECHNOLOGY ASSESSMENT AND MARKET PENETRATION

0 TO 2 YEAR SIMPLE PAYBACK PERIOD:

BTU METER

CORE COMMERCIAL DAYLIGHTING

OPERATING AND MAINTENANCE PROCEDURES

VACUUM STEAM RADIATORS

3 TO 5 YEAR SIMPLE PAYBACK PERIOD:

ABSORPTION CHILLER

ACOUSTIC LEAK DETECTION SYSTEM

ADVANCED DUCT SEALING TECHNIQUES

ADVANCED RANKINE CYCLE HEAT PUMP

COMMERCIAL BUILDING RETROFIT PROCEDURES

DIAGNOSTIC PROTOCOLS AND ANALYSIS METHODS

HEAT PUMP (QUASI OPEN CYCLE)

ICE SLURRY EVAPORATOR

MOBILE HOME RETROFIT PROCEDURES

MULTIFAMILY AUDIT HANDBOOK

MULTIFAMILY RETROFIT PROCEDURES

PUBLIC HOUSING RETROFIT PROCEDURES

SHARED SAVINGS

URBAN HEAT ISLANDS

6 TO 10 YEAR PAYBACK PERIOD:

NON-METALLIC PIPING SYSTEM

MORE THAN 10 YEAR PAYBACK PERIOD:

DOWN-HOLE HEAT EXCHANGER

BUILDING SYSTEMS DIVISIOH

NO RESPONSE TO QUESTION 4:

ADVANCED DESIGN TOOLS

PROPOR

THERMAL CONDUCTIVITY MEASUREMENTS OVER RANGE OF ENVIRONMENTAL TEMPS.

SIMPLIFIED THERMAL ANALYSIS OF ROOFS (STAR)

NON-APPLICABLE:

ACOUSTIC TESTING OF ATTIC INSULATION

ADVANCED LEAKAGE TECHNIQUES

ALTERNATIVE CFC-BASED INSULATIONS IN WALL AND FOUNDATION SYSTEMS

CORROSIVENESS OF INSULATION

ENERGY KERNEL SYSTEM

FOAM AGING AND R-VALUE PREDICTION

IMBEDDED HEAT FLUX TRANSDUCERS

LOOSE FILL ATTIC INSULATION SETTLING

MAINTENANCE AND UPGRADING OF DOE-2

B. 6 
IABLE B.2. (contd)

MATHEMATICAL MODELING OF INDOOR AIR QUALITY

MOISTURE GUIDELINES FOR RESIDENCES

MOISTURE IMPACTS ON MATERIALS

MULTI-ZONAL INF ILTRATION AND VENTILATION MEASUREMENT

PASSIVE SAMPLER OF VOLATILE DRGANIC COMPOUNDS (VOC)

PERFLUOROCARBON TRACER SYSTEM

RADIANT BARRIER CLIMATIC GUIDE

RADIATIVE HEAT TRANSFER

SICK BUILDING SYNDROME PROTOCOL

SUBSTITUTE FOAMING AGENTS FOR INSULATION

WINDOW 3.1 COMPUTER PROGRAM

0 TO 2 YEAR PAYBACK PERIOD:

ADVANCED RESIDENTIAL VENTILATION SYSTEMS

COMANERIAL STANDARDS

FOUNDATION DESIGN TOOLS INCLUDING HANDBOOKS

SMALL OFFICE BUILDING HANDBOOK

SUPERLITE

3 TO 5 YEAR PAYBACK PERIOD:

ADVANCED DURABLE LOW-E COATINGS

AERATED AUTOCLAVED CONCRETE

FIELD THERMAL PERFORMANCE METHODOLOGY

HIGH-R WINDOWS

HVAC/LIGHTING INTERACTIONS

MANUFACTURED HOUSING INSULATION

MOISTURE MEASUREMENT METHODOLOGY

NON-INTRUSIVE MOISTURE PROBE

ROOF RESEARCH CENTER - A NATIONAL USER FACILITY

ROOF SURFACE TREATMENT GUIDELINES

ROOF THERMAL RESEARCH APPARATUS (RTRA)

THERMAL BRIDGES DESIGN CATALOG

6 TO 10 YEAR PAYBACK PERIOD:

COMPOSITE/PRE-BUILT WALL SYSTEMS

LARGE SCALE CLIMATE SIMULATOR (LSCS)

POWDER-FILLED EVACUATED INSULATION PANELS

RADIANT BARRIER SYSTEMS

SWITCHABLE E MATERIALS

VARIABLE $R$ MATERIALS 
TABLE B.3. Energy-Related Benefits of A11 Technologies

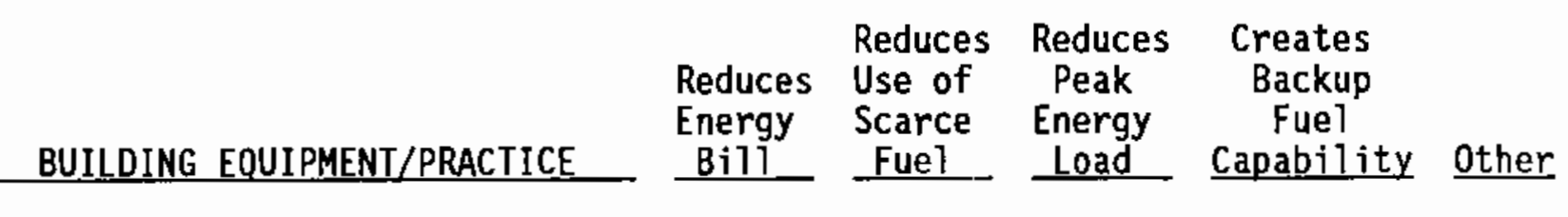

BUILDING EQUIPMENT DIVISION

ABSORPTION FLUIDS

OTHER BENEFITS: PART OF HEAT

PUMP

ADVANCED CONCEPT ABSORPTION HEAT PUMP

ADVANCED CONDENSING HEAT

EXCHANGERS

ADVANCED INSULATION

ADVANCED LIGHTING CONTROLS

ADVANCED PHOSPHOR MATERIALS

$x \quad x \quad x$

CERAMIC FLUID PUMPS(a)

COMMERCIAL AND RESIDENTIAL ZONING

CONSERVATION MEASURES THROUGH FORCED-AIR DISTRIBUTION

DESICCANT/HYBRID COOLING
SYSTEMS

DIRECT VENT TECHNOLOGY

$x \quad x$

$x \quad x$

$x$

$x$

$x \quad x$

$x$

DYNAMIC LIGHTING DESIGN

$x \quad x$

$x$

$x$

EJECTOR COUPLED HP CYCLE(a)

ELECTRODELESS HIGH-INTENSITY

DISCHARGE LIGHT

FIFTEEN-TON BRAUN LINEAR ENGINE HP.

FUEL-OIL ATOMIZATION/COMBUSTION

$\mathrm{x}$

$x$

$x$

$x \quad x$

$x$

HERMETIC COMPRESSOR SEALS(a) 
IABLE B.3. (contd)

\begin{tabular}{|c|c|c|c|c|c|}
\hline BUILDING EQUIPMENT/PRACTICE & $\begin{array}{l}\text { Reduces } \\
\text { Energy } \\
\text { Biti } \\
\end{array}$ & $\begin{array}{l}\text { Reduces } \\
\text { Use of } \\
\text { Scarce } \\
\text { Fue? } \\
\end{array}$ & $\begin{array}{l}\text { Reduces } \\
\text { Peak } \\
\text { Energy } \\
\text { Load } \\
\end{array}$ & $\begin{array}{l}\text { Creates } \\
\text { Backup } \\
\text { Fuel } \\
\text { Capability } \\
\end{array}$ & other \\
\hline IN VITRO DIAGNOSTICS & $x$ & $\mathrm{x}$ & $\mathrm{x}$ & & \\
\hline $\begin{array}{l}\text { INCANDESCENT REPLACEMENT BY } \\
\text { H.I.D. }\end{array}$ & $x$ & & $x$ & & \\
\hline ISOTOPICALLY ENRICHED FLUORESCENT & $x$ & & $x$ & & \\
\hline $\begin{array}{l}\text { LOW-FIRING RATE OIL BURNER } \\
\text { TECHNOLOGY }\end{array}$ & $x$ & $x$ & & & \\
\hline $\begin{array}{l}\text { NONAZEOTROPIC REFRIGERANT } \\
\text { MIXTURES }\end{array}$ & $x$ & $x$ & $x$ & & \\
\hline $\begin{array}{l}\text { OPTIMIZED GROUND COUPLED HEAT } \\
\text { PUMP }\end{array}$ & $x$ & & $x$ & & \\
\hline PERFORMANCE CONTROL STRATEGIES & $x$ & $x$ & & & \\
\hline $\begin{array}{l}\text { SOLID FUEL APPLIANCE MEASUREMENT } \\
\text { METHODS }\end{array}$ & $x$ & $x$ & & $x$ & \\
\hline STIRLING/RANK. DIA. COUPLED MP. & $x$ & $x$ & $x$ & & \\
\hline SURFACE WAVE FLUORESCENT & $x$ & & $x$ & & \\
\hline $\begin{array}{l}\text { VARIABLE-SPEED COMPRESSORS \& } \\
\text { FANS }\end{array}$ & $x$ & $x$ & $x$ & & \\
\hline WOOD COMBUSTION SYSTEMS & $x$ & $x$ & & $x$ & \\
\hline \multicolumn{6}{|l|}{ BUILDING SERVICES DIVISIDH } \\
\hline ABSORPTION CHILLER & & & $x$ & & \\
\hline ACOUSTIC LEAK DETECTION SYSTEM & & $x$ & & & \\
\hline $\begin{array}{l}\text { ADVANCED DUCT SEALING TECHNIQUES } \\
\text { OTHER BENEFITS: INCREASES } \\
\text { EFFECTIVE LIFE OF HVAC } \\
\text { EQUIPMENT }\end{array}$ & $x$ & $x$ & $x$ & & $x$ \\
\hline ADVANCED RANKINE CYCLE HEAT PUMP & $\mathbf{x}$ & $x$ & & & \\
\hline
\end{tabular}


IABLE B.3. (contd)

\begin{tabular}{|c|c|c|c|c|c|}
\hline BUILDING EQUIPMENT/PRACTICE & $\begin{array}{l}\text { Reduces } \\
\text { Energy } \\
\text { Bill } \\
\end{array}$ & $\begin{array}{l}\text { Reduces } \\
\text { Use of } \\
\text { Scarce } \\
\text { Fuel } \\
\end{array}$ & $\begin{array}{l}\text { Reduces } \\
\text { Peak } \\
\text { Energy } \\
\text { Load } \\
\end{array}$ & $\begin{array}{l}\text { Creates } \\
\text { Backup } \\
\text { Fuel } \\
\text { Capability } \\
\end{array}$ & other \\
\hline $\begin{array}{l}\text { ANALYTICAL TOOLS } \\
\text { OTHER BENEFITS: REDUCES ENERGY } \\
\text { CONSUMPTION }\end{array}$ & $x$ & & $x$ & & $x$ \\
\hline BTU METER & $x$ & & & & \\
\hline $\begin{array}{l}\text { COMMERCIAL BUILDING RETROFIT } \\
\text { PROCEDURES }\end{array}$ & $x$ & & & & \\
\hline CORE COMMERCIAL DAYLIGHTING & & $x$ & & $x$ & \\
\hline $\begin{array}{l}\text { DIAGNOSTIC PROTOCOLS AND } \\
\text { ANALYSIS METHODS }\end{array}$ & $x$ & $x$ & $x$ & & \\
\hline $\begin{array}{l}\text { DIAGNOSTIC TOOL DEVELOPMENT } \\
\text { OTHER BENEFITS: CAN PROVIDE } \\
\text { EMPIRICAL EVIDENCE OF EFFI- } \\
\text { CIENCY IMPROVEMENT } \\
\text { POST-RETROFIT }\end{array}$ & & & & & $x$ \\
\hline DOWN-HOLE HEAT EXCHANGER & & $x$ & & & \\
\hline ENERGY TRACKING SYSTEM & $x$ & & & & \\
\hline FRICTION REDUCTION ADDITIVES & $x$ & $x$ & $x$ & & \\
\hline HEAT PUMP (QUASI OPEN CYCLE) & & $x$ & $x$ & & \\
\hline ICE SLURRY EVAPORATOR & $x$ & & $x$ & & \\
\hline $\begin{array}{l}\text { INTEGRATED UTILITY PLANNING } \\
\text { PROCESSES } \\
\text { OTHER BENEFITS: REDUCES ENERGY } \\
\text { CONSUMPTION }\end{array}$ & $x$ & & $x$ & & $x$ \\
\hline MOBILE HOME RETROFIT PROCEDURES & $x$ & & & & \\
\hline MULTIFAMILY AUDIT HANDBOOK & $x$ & & & & \\
\hline MULTIFAMILY RETROFIT PROCEDURES & $x$ & & & & \\
\hline NON-METALLIC PIPING SYSTEM & & $x$ & & & \\
\hline
\end{tabular}


IABLE B.3. (contd)

\begin{tabular}{|c|c|c|c|c|c|}
\hline BUILDING EQUIPMENT/PRACTICE & $\begin{array}{l}\text { Reduces } \\
\text { Energy } \\
\text { Bili } \\
\end{array}$ & $\begin{array}{l}\text { Reduces } \\
\text { Use of } \\
\text { Scarce } \\
\text { Fuel } \\
\end{array}$ & $\begin{array}{l}\text { Reduces } \\
\text { Peak } \\
\text { Energy } \\
\text { Load } \\
\end{array}$ & $\begin{array}{c}\text { Creates } \\
\text { Backup } \\
\text { Fue] } \\
\text { Capability } \\
\end{array}$ & other \\
\hline $\begin{array}{l}\text { OPERATING AND MAINTENANCE } \\
\text { PROCEDURES }\end{array}$ & $x$ & & & & \\
\hline $\begin{array}{l}\text { PUBLIC HOUSING RETROFIT } \\
\text { PROCEDURES }\end{array}$ & $x$ & & $x$ & & \\
\hline RADIANT BARRIER CLIMATIC GUIDE & $x$ & & $x$ & & \\
\hline RADIANT BARRIER MODELING & $x$ & & & & \\
\hline SHARED SAVINGS & $x$ & $x$ & $x$ & & \\
\hline $\begin{array}{l}\text { STRATEGIES FOR EMERGING ISSUES } \\
\text { OTHER BENEFITS: REDUCES ENERGY } \\
\text { CONSUMPTION }\end{array}$ & $x$ & & $x$ & & $x$ \\
\hline $\begin{array}{l}\text { TECHNOLOGY ASSESSMENT AND MARKET } \\
\text { PENETRATION } \\
\text { OTHER BENEFITS: REDUCES ENERGY } \\
\text { CONSUMPTION }\end{array}$ & $x$ & & $x$ & & $x$ \\
\hline $\begin{array}{l}\text { URBAN HEAT ISLANDS } \\
\text { OTHER BENEFITS: ENVIRONMENT- } \mathrm{CO}_{2} \\
\text { EMISSIONS REDUCED }\end{array}$ & $x$ & & $x$ & & $x$ \\
\hline VACUUM STEAM RADIATORS & & $x$ & $x$ & & \\
\hline \multicolumn{6}{|l|}{ BUILDING SYSTEMS DIVISION } \\
\hline $\begin{array}{l}\text { ACOUSTIC TESTING OF ATTIC } \\
\text { INSULATION } \\
\text { OTHER BENEFITS: MORE INSULATION } \\
\text { PER DOLLAR }\end{array}$ & & & & & $x$ \\
\hline $\begin{array}{l}\text { ADVANCED DESIGN TOOLS } \\
\text { OTHER BENEFITS: INCREASE UTILI- } \\
\text { ZATION OF ENERGY EFFICIENT } \\
\text { DESIGNS }\end{array}$ & $x$ & $x$ & & & $x$ \\
\hline ADVANCED DURABLE LOW-E COATINGS & $\mathrm{x}$ & $x$ & $\mathbf{x}$ & & \\
\hline
\end{tabular}


IABLE B.3. (contd)

\begin{tabular}{|c|c|c|c|c|c|}
\hline BUILDING EQUIPMENT/PRACTICE & $\begin{array}{l}\text { Reduces } \\
\text { Energy } \\
\text { Bill } \\
\end{array}$ & $\begin{array}{l}\text { Reduces } \\
\text { Use of } \\
\text { Scarce } \\
\text { Fuel } \\
\end{array}$ & $\begin{array}{l}\text { Reduces } \\
\text { Peak } \\
\text { Energy } \\
\text { Load }\end{array}$ & $\begin{array}{l}\text { Creates } \\
\text { Backup } \\
\text { Fuel } \\
\text { Capability } \\
\end{array}$ & 0ther \\
\hline $\begin{array}{l}\text { ADVANCED LEAKAGE TECHNIQUES } \\
\text { OTHER BENEFITS: WOULD ALLOW FOR } \\
\text { INCREASED ACCURACY OF ENERGY } \\
\text { LIABILITY }\end{array}$ & & & & & $x$ \\
\hline $\begin{array}{l}\text { ADVANCED RESIDENTIAL VENTILATION } \\
\text { SYSTEMS }\end{array}$ & $x$ & & & & $x$ \\
\hline $\begin{array}{l}\text { OTHER BENEFITS: IMPROVE INDOOR } \\
\text { AIR QUALITY }\end{array}$ & & & & & \\
\hline AERATED AUTOCLAVED CONCRETE & $x$ & $x$ & $x$ & & \\
\hline $\begin{array}{l}\text { ALTERNATIVE CFC-BASED INSULA- } \\
\text { TIONS IN WALL AND FOUNDATION } \\
\text { SYSTEMS }\end{array}$ & & & & & \\
\hline COMMERCIAL STANDARDS & $x$ & $x$ & $x$ & & \\
\hline COMPOSITE/PRE-BUILT WALL SYSTEMS & $x$ & & & & \\
\hline $\begin{array}{l}\text { CORROSIVENESS OF INSULATION } \\
\text { OTHER BENEFITS: REDUCES DETE- } \\
\text { RIORATION OF BUILDING STRUCTURES }\end{array}$ & & & & & $x$ \\
\hline ENERGY KERNEL SYSTEM & $x$ & & $x$ & & \\
\hline $\begin{array}{l}\text { FIELD THERMAL PERFORMANCE } \\
\text { METHODOLOGY } \\
\text { OTHER BENEF ITS: ALERTS ABOUT } \\
\text { ACTUAL THERMAL PERFORMANCE IN } \\
\text { THE FIELD }\end{array}$ & & & & & $x$ \\
\hline $\begin{array}{l}\text { FOAM AGING AND R-VALUE } \\
\text { PREDICTION. }\end{array}$ & $x$ & & $x$ & & \\
\hline $\begin{array}{l}\text { FOUNDATION DESIGN TOOLS INCLUD- } \\
\text { ING HANDBOOKS }\end{array}$ & $x$ & $x$ & & & \\
\hline HIGH-R WINDOWS & $x$ & $x$ & & & \\
\hline HVAC/LIGHTING INTERACTIONS & $x$ & & $x$ & & \\
\hline
\end{tabular}


TABLE B.3. (contd)

\begin{tabular}{|c|c|c|c|c|c|}
\hline BUILDING EQUIPMENT/PRACTICE & $\begin{array}{l}\text { Reduces } \\
\text { Energy } \\
\text { Bilf } \\
\end{array}$ & $\begin{array}{l}\text { Reduces } \\
\text { Use of } \\
\text { Scarce } \\
\text { Fuel } \\
\end{array}$ & $\begin{array}{l}\text { Reduces } \\
\text { Peak } \\
\text { Energy } \\
\text { Load } \\
\end{array}$ & $\begin{array}{c}\text { Creates } \\
\text { Backup } \\
\text { Fuel } \\
\text { Capability } \\
\end{array}$ & other \\
\hline $\begin{array}{l}\text { IMBEDDED HEAT FLUX TRANSDUCERS } \\
\text { OTHER BENEF ITS: INCREASES UNDER- } \\
\text { STANDING OF HEAT FLOW IN } \\
\text { BUILDINGS }\end{array}$ & & & & & $x$ \\
\hline $\begin{array}{l}\text { LARGE SCALE CLIMATE SIMULATOR } \\
\text { (LSCS) } \\
\text { OTHER BENEFITS: SAVES ENERGY OR } \\
\text { EXTENDS SERVICE LIFE OF ROOFS } \\
\text { BY SOLVING A PROBLEM OR REC- } \\
\text { OMMENDING A PRACTICE }\end{array}$ & & & & & $x$ \\
\hline $\begin{array}{l}\text { LOOSE FILL ATTIC INSULATION } \\
\text { SETTLING }\end{array}$ & $x$ & & & & \\
\hline $\begin{array}{l}\text { MAINTENANCE AND UPGRADING OF } \\
\text { DOE-2 } \\
\text { OTHER BENEFITS: PROVIDES } \\
\text { CAPABILITY TO SIMULATE THERMAL. } \\
\text { PERFORMANCE OF BUILDINGS }\end{array}$ & & & & & $x$ \\
\hline MANUFACTURED HOUSING INSULATION & $x$ & & $x$ & & \\
\hline $\begin{array}{l}\text { MATHEMATICAL MODELING OF INDOOR } \\
\text { AIR QUALITY } \\
\text { OTHER BENEFITS: IMPROVED } \\
\text { VENTILATION DESIGN }\end{array}$ & & & & $x$ & \\
\hline $\begin{array}{l}\text { MOISTURE GUIDELINES FOR } \\
\text { RESIDENCES }\end{array}$ & & & & & \\
\hline MOISTURE IMPACTS ON MATERIALS & $x$ & & $x$ & & \\
\hline $\begin{array}{l}\text { MOISTURE MEASUREMENT METHODOLOGY } \\
\text { OTHER BENEFITS: INDIRECTLY } \\
\text { SAVES ENERGY BY ALERTING TO } \\
\text { LOSS OF ROOF THERMAL } \\
\text { PERFORMANCE }\end{array}$ & & & & & $x$ \\
\hline $\begin{array}{l}\text { MULTI -ZONAL INF ILTRATION AND } \\
\text { VENTILATION MEASUREMENT } \\
\text { OTHER BENEFITS: OPIIMIZED } \\
\text { VENTILATION DESIGNS }\end{array}$ & & & & & $x$ \\
\hline
\end{tabular}


IABLE B.3. (contd)

BUILDING EQUIPMENT/PRACTICE

\begin{tabular}{lllc} 
Reduces & $\begin{array}{l}\text { Reduces } \\
\text { Use of }\end{array}$ & $\begin{array}{c}\text { Reduces } \\
\text { Peak }\end{array}$ & $\begin{array}{c}\text { Creates } \\
\text { Backup }\end{array}$ \\
Energy & Scarce & Energy & Fue1 \\
Bill & Fuel & Load & Capability \\
\hline
\end{tabular}

Qther

NON-INTRUSIVE MOISTURE PROBE

OTHER BENEFITS: ALERTS TO LOSS

OF THERMAL PERFORMANCE AND

ROOF LIFE, AND INDIRECTLY

SAVES ENERGY

PASSIVE SAMPLER OF VOLATILE ORGANIC COMPOUNDS

OTHER BENEFITS: MAY LEAD TO

OPTIMIZED VENTILATION IN

BUILDINGS

PERFLUOROCARBON TRACER SYSTEM

OTHER BENEFITS: OPTIMIZED

VENTILATION

POWDER-FILLED EVACUATED

INSULATION PANELS

PROPOR

RADIANT BARRIER SYSTEMS

$x$

RADIATIVE HEAT TRANSFER

OTHER BENEFITS: SAVES ENERGY

INDIRECTLY THROUGH BETTER

DESIGN

ROOF RESEARCH CENTER-A NATIONAL USER FACILITY

OTHER BENEFITS: INDIRECTLY

SAVES ENERGY OR EXTENDS ROOF

LIFE BY SOLVING A PROBLEM OR

RECOMMENDING A PRACTICE

ROOF SURFACE TREATMENT GUIDELINES

ROOF THERMAL RESEARCH APPARATUS

$x$

$x$

$x$ (RTRA)

OTHER BENEFITS: HELPS TO SAVE ENERGY BY SOLVING A PROBLEM OR RECOMMENDING A PRACTICE 
IABLE B.3. (contd)

\begin{tabular}{|c|c|c|c|c|c|}
\hline BUILDING EQUIPMENT/PRACTICE & $\begin{array}{l}\text { Reduces } \\
\text { Energy } \\
\text { Bil1 }\end{array}$ & $\begin{array}{l}\text { Reduces } \\
\text { Use of } \\
\text { Scarce } \\
\text { Fuel } \\
\end{array}$ & $\begin{array}{l}\text { Reduces } \\
\text { Peak } \\
\text { Energy } \\
\text { Load } \\
\end{array}$ & $\begin{array}{l}\text { Creates } \\
\text { Backup } \\
\text { Fuel } \\
\text { Capability } \\
\end{array}$ & 0ther \\
\hline $\begin{array}{l}\text { SICK BUILDING SYNDROME PROTOCOL } \\
\text { OTHER BENEFITS: OPTIMAL } \\
\text { VENTILATION }\end{array}$ & & & & & $x$ \\
\hline $\begin{array}{l}\text { SMALL OFFICE BUILDING HANDBOOK } \\
\text { OTHER BENEFITS: CONTROLS } \\
\text { SIGNIFICANT VARIABLE ON RENTAL } \\
\text { PROPERTY AND AN EDGE ON THE } \\
\text { UNINFORMED CONPETITION }\end{array}$ & $x$ & & $x$ & & $x$ \\
\hline $\begin{array}{l}\text { SIMPL IF IED THERMAL ANALYSIS OF } \\
\text { ROOFS (STAR) } \\
\text { OTHER BENEFITS: DETERMINES } \\
\text { ACTUAL THERMAL }\end{array}$ & & & & & $x$ \\
\hline $\begin{array}{l}\text { PERFORMANCE AND TEMP. CONDITIONS } \\
\text { OF COHPOSITE ROOFS IN THE FIELD }\end{array}$ & & & & & \\
\hline $\begin{array}{l}\text { SUBSTITUTE FOAMING AGENTS FOR } \\
\text { INSULATION } \\
\text { OTHER BENEFITS: PROVIDES } \\
\text { EFFECTIVE INSULATION IF CFC'S } \\
\text { ARE BANNED }\end{array}$ & $x$ & & & & $x$ \\
\hline SUPERLITE & $x$ & $x$ & $x$ & & \\
\hline SWITCHABLE E MATERIALS & $x$ & & $x$ & & \\
\hline THERMAL BRIDGES DESIGN CATALOG & $x$ & $x$ & & & \\
\hline $\begin{array}{l}\text { THERMAL CONDUCTIVITY MEASURE- } \\
\text { MENTS OVER RANGE OF ENVIRON- } \\
\text { MENTAL TEMPS. }\end{array}$ & & & & & \\
\hline VARIABLE R MATERIALS & $x$ & & $x$ & & \\
\hline $\begin{array}{l}\text { WINDOW 3.I COMPUTER PROGRAM } \\
\text { OTHER BENEFITS: DESIGN AND } \\
\text { SELECTION OF ENERGY EFFICIENT } \\
\text { WINDOWS }\end{array}$ & $x$ & & & & $x$ \\
\hline
\end{tabular}

(a) No energy-related benefits identified. 
TABLE B.4. Non-Energy Benefits of A11 Technologies

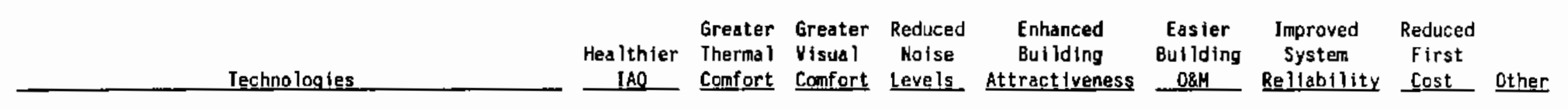

\section{BUILDIRG EQUIPHEMI DIVISION}

ABSORPIION FLUIDS

OTHER: PART OF HEAT PUMP

ADVARCED COHCEPT ABSORPTION HEAT PUHP

ADVANCED CONDENSING HEAT EXCHANGERS

ADVANCED INSULATION

ADVANCED LIGHTIRG CONTROLS

ADVANCED PHOSPHOR MATERIALS

का

CERAMIC FLUID PUMPS

COMMERCIAL AND RESIDENTIAL ZONING

CONSERVATION MEASURES THROUGH FORCED-AIR DISTRIBUTION

OESICCANT/HYRR!O COQLING SYSTEMS(A)

DIRECT VENT TECHNOLOGY

DYNAMIC LIGHIING DESIGM

EJECTOR COUPLED HP CYCLE(a)

ELECTROOELESS HIGH-IMTENSITY DISCHARGE LIGHT

FIFTEEN-TON BRAUN LINEAR ENGINE HP.

FUEL-OIL ATOMIZATION/COMBUSTION

HERMETIC COMPRESSOR SEALS ${ }^{(a)}$

IN VITRO DIAGNOSTICS $x$

$x$

$x$

$x$

$x$

$x$

$x$

$x$

$x$

$x$

\begin{tabular}{|c|c|c|}
\hline \multirow[t]{3}{*}{$x$} & \multirow{3}{*}{$x$} & $x$ \\
\hline & & $x$ \\
\hline & & $x$ \\
\hline
\end{tabular}

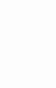

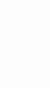

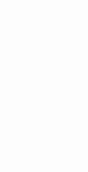


TABLE B.4. (contd)

Technologies

Greater Greater Reduced

Healthier Thermal Visual Noise

IAQ Comfort Comfort Levels. Attractiveness

Enhanced

Building

Easíar

Building

Improves Reduced

System First

INCANDESCENT REPLACEMENT BY H.l.D.

ISOTOPICALLY ENRICHEO FLUDRESCENT

LOW-FIRING RATE OIL BURKER TECHNOLOGY

NONAZEOTROPIC REFRIGERANT MIXTLRES

OPTIHIZEO GROUND COUPLEO HEAT PUMP

PERFORMANCE CONTROL STRATEgIES

SOLID FUEL APPLIANCE MEASUREMENT METHODS

OTHER: QUANTIFIES ENERGY SAYINGS

STIRLING/RANK. DIA. COUPLEO HP.

च SURface wave FLUORESCENT

YARIABLE-SPEED COMPRESSORS FANS

WOOO COMBUSTION SYSTEMS

$x$

\section{BUILDING SERUICES DIVISIOY}

ABSORPTION CHILLER

ACOUSTIC LEAK DETECTION SYSTEH

ADVANCED OUCT SEALING TECHMIQUES

ADVAHCED RANKINE CYCLE HEAT PUMP

ANALYTICAL TOOLS

OTHER: REDUCE $\mathrm{CO}_{2}$ INPUT INTO THE ATMOSPHERE

BTU METER

$\begin{array}{ccc}x & x & x \\ x & & x \\ & x & x \\ x & & x\end{array}$

$x$

$x$ $\mathbf{x}$

$\mathbf{x}$

$x$

$x$

$\mathbf{x}$

$\mathbf{x}$

$x$

$x$

$x$

$x$

X

$x$

$x$

$x$

$x$

$x$

$x$

$x$

$x$

$x$

$x$

$x$ $x$

$x$

X

X 
IABLE B.4. (contd)

Greater Greater Reduced

Technologies

IAO

Visual

Enhanced

Easter

Buflding

Butlding

Improves

Reduced

Comfort Comfort Levels Attractiveness

O8H

stem first

COMMERCIAL BUILDING RETROFIT PROCEDURES

OIAGMOSTIC PROTOCOLS ANO ANALYSIS METHODS

OTHER: PROVIOES CAPITAL TO INVEST IN BETTER

OPPORTUNITIES

DIAGNOSTIC TOOL DEVELOPMENT

DOHN-HOLE HEAT EXCHANGER

ENERGY TRACKING SYSTEM

FRICTION REDUCTIOH ADOITIVES

HEAT PUMP (QUASI OPEN CYCLE)

ICE SLURRY EVAPORATOR

INTEGRATED UTILITY PLANHING PROCESSES

OTHER: PEDUCED $\mathrm{CO}_{2}$ INPUT INTO THE ATMOSPHERE

MDBILE hOME RETROFIt PROCEOURES

$x$

$x$

MULTIFAMILY AUDIT HANDBOOK

MULTIFAHILY RETROFIT PROCEOURES

NOH-METALLIC PIPING SYSTEM

OPERATING AND MAINTENANCE PROCEDURES

PUBLIC HOUSIHG RETROFIT PROCEDURES

$x$

$\mathbf{X}$

$x$

$x$

$x \quad x$

$x$

$x$

$x$

RADIANT BARRIER CLIMATIC GUIDE

RADIANT BARRIER MODELING 


\section{IABLE B.4. (contd)}

Greater Greater Reduced

Thermal Visual Nolse

Erhanced

Buliding

Easier Butidting

Improves

Reduced

Technologies

$\mathbf{x}$

SHARED SAVINGS

OTHER: PROVIDES CAPITAL TO INVEST IN BETTER

OPPORTUNITIES

STRATEGIES FOR EMERGING ISSUES

OTHER: REDUCEO $\mathrm{CO}_{2}$ INPIT INTO THE ATMOSPHERE

TECHROLOGY ASSESSHENT AND MARKET PERETRATION

OTHER: REOUCEO $\mathrm{CO}_{2}$ INPUT INTO THE ATMOSPHERE

URBAN HEAT ISLANDS

OTHER: COOLER SUMHER AIR TEMPS IH URBAN AREAS;

AESTHETICS OF CITY

VACUUM STEAM RADIATORS

i BUILDING SYSTEIS DIYISIOH

ACOUSTIC TESTING OF ATTIC INSULATION

ADVAMCEO OESIGH TOOLS

ADVANCED OURABLE LOU-E COATIKGS

$x$
$x$
$x$
$x$
$x$

AERATED AUTOCLAVED CONCRETE

ALTERNATIVE CFC-BASED INSULATIONS IH WALL ANO FOURDATION SYSTEWS

OTHER: HEALTHIER OUTOOOR ENVIRONHENT

COMMERCIAL STANDAROS

COMPOSITE/PRE-BUILT WALL SYSTEMS

$\begin{array}{lll}x & x & x \\ x & x\end{array}$

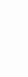

$x$ 
IABLE B.4. (contd)

Greater Greater Reduced

Theme 1

Enhanced

Butiding

Easter

Butlding

Improves Reduced

Technologies

Confort Comfort Levels Attractiveness

$x$

CORROSIVENESS OF INSULATION

$x \quad x$

FIELD THERMAL PERFORMAKCE METHODOLOGY

FOAM AGING AND R-VALUE PREDICTION

FOUNDATION DESIGN TOOLS INCLUDING HANDBOOKS

OTHER: REDUCES MOISTURE/CONOENSATION

HIGH-R WINOOWS

HVAC/LIGHTING INTERACTIONS

OTHER: REDUCES USE OF COAL-GENERATED ELECTRICITY

AND HENCE ENVIROLMENTAL IMPACT

ऽ IMBEDDED HEAT FLLUX TRANSDUCERS

LARGE-SCALE CLIMATE SIMULATOR (LSCS)

InOSE-FIII ATTIC IKSULATION SETTLING

MAINTENANCE AND UPGRADING OF DOE-2

MANUFACTURED HOUSING INSULATION

MATHEMATICAL MODELING OF INDOOR AIR QUALITY

MOISTURE GUIDELINES FOR RESIDENCES

MOISTURE IMPACTS ON MATERIALS

MOISTURE MEASUREMENT METHDDOLOGY

MULTI-ZONAL IHFILTRATION AND VEHTILATION MEASUREMENT

HON-INTRUSIVE MOISTURE PRDEE

$x$

$x$

$\mathbf{x}$

$x$ $x$

$x$

$\mathbf{x}$

$x$

$x \quad x$

$x$

$x$

$x$

$x \quad x$

$x \quad x$

$x$

$x$

$x$ 


\section{IABLE B.4. (contd)}

Technologies

PASSIVE SAMPLER OF VOLATILE ORGANIC COMPOUHOS (VOC)

PERFLLUROCARBON TRACER SYSTEM

POHDER-FILLEO EVACUATED INSULATION PARELS

PROPOR

RADIANT BARRIER SYSTEMS

RADIATIVE HEAT TRAHSFER

OTHER: INCREASES OUR UNDERSTANDING OF HEAT TRANSFER

ROOF RESEARCH CENTER - A NATIONAL USER FACILITY

ه RDOF SURFACE TREATMENT GUIDELINES

iv ROOF THERMAL RESEARCH APPARATUS (RTRA)

SICK BUILOIKG SYNDROME PROTOCOL

SIMPLIFIED THERMAL ANALYSIS OF ROOFS (STAR)

SHALL OFFICE BUILOING HAHOBOOK

SUBSTITUTE FOAMING AGENTS FOR INSULATION

OTHER: HEALTHIER AND MORE COMFORTABLE OUTDOOR ENVIRONHENT

SUPERLITE

OTHER: IMPROYED WORKER PRODUCTIYITY

SHITCHABLE E MATERIALS

THERMAL BRIOGES DESIGN CATALOG

OTHER: REDUCES MOISTURE DAMAGE
Greater Greater Reduced

Healthier Thermal Visual Noise IAO

comfort Confort Levels

Enhanced

Building

Easfer

Butlding

Improves

System

Reduced

$x$

x

$x$

$x$

$x$

$x$

x

$x$

$x$

$\mathbf{x}$

$x$

X 
TABLE B.4. (contd)

\begin{tabular}{|c|c|c|c|c|c|c|c|c|}
\hline & $\begin{array}{l}\text { Healthier } \\
\text { IAO }\end{array}$ & $\begin{array}{l}\text { Greater } \\
\text { Therma } 1 \\
\text { Comfort }\end{array}$ & $\begin{array}{l}\text { Greater } \\
\text { Visual } \\
\text { Confort }\end{array}$ & $\begin{array}{l}\text { Reduced } \\
\text { Noise } \\
\text { Levels }\end{array}$ & $\begin{array}{l}\text { Enhanced } \\
\text { Bul lding } \\
\text { Attractiveness }\end{array}$ & $\begin{array}{c}\text { Easier } \\
\text { Building } \\
\text { O\&H }\end{array}$ & $\begin{array}{l}\text { Improves } \\
\text { System } \\
\text { Rellability }\end{array}$ & $\begin{array}{l}\text { Reduced } \\
\text { Ftrst } \\
\text { Cost }\end{array}$ \\
\hline
\end{tabular}

THERMAL CONDUCTIVITY MEASUREMENTS OVER RANGE OF ENVIRONMENTAL TEMPS.

VARIABLE R MATERIALS

UIMDOU 3.1 COMPUTER PROGRAM

$x$

(a) No non-energy-related barriers ident if ied. 


\section{IABLE B.5. Commercialization Barriers for All Technologies}

\begin{tabular}{lcc} 
Simple Barriers \\
\hline Lack of Lack of & Number of Reli- \\
Aware- & Under- & Decision ability
\end{tabular}

Serlaus Barrters

Iechnologies

ness standing

Makers. Concerns

Environ- Bullding

Lega 1/

Financing High High

Concerns Conflicts Difffculties ability Risk Cost other

\section{BUILDIHG EOUIPMEHT DIVISIOH}

ABSORPTION FLUIOS

OTHER BARRIERS: PART OF HEAT PUMP

ADVANCED CONCEPT ABSORPTION HEAT PUMP

AOVANCED CONDEHSING HEAT

EXCHANGERS

AOVANCED INSULATION

OTHER BARRIERS: LACK OF A

FEASIBLE MFR PROCESS

ADVARCEO IIGHTING CONTROLS

OTHER BARR IERS: LITTLE INCENTIVE TO USE

ADVANCED PHOSPHOR MATERIALS

CERAMIC FLUID PLHPS

OTHER BARRIERS: N/A PART OF HEAT PUMP

COMAERCIAL ANO RESIOENTIAL ZONING

CONSERVATIOH MEASURES THROUGH FORCEO-AIR DISTRIQUTION

DESICCANT/HYRRID COOLIKG SYSTEMS (a)

DIRECT VENT TECHNOLOGY

DYNAHIC LIGHTING DESIGN

DTHER BARRIERS: LITTLE INCENTIVE

$x \quad x$

$x$

$\mathbf{X}$

$x$

$x$ 
IABLE B.5. (contd)

\begin{tabular}{|c|c|c|c|c|c|c|c|c|c|}
\hline \multicolumn{4}{|c|}{ Simple Barriers } & \multicolumn{6}{|c|}{ Serlous Barriers } \\
\hline $\begin{array}{l}\text { ack of } \\
\text { ware- } \\
\text { ness } \\
\end{array}$ & $\begin{array}{l}\text { Lack of } \\
\text { Under- } \\
\text { standing }\end{array}$ & $\begin{array}{l}\text { Large } \\
\text { Number of } \\
\text { Dects ion } \\
\text { Makers }\end{array}$ & $\begin{array}{l}\text { Reli- } \\
\text { ability } \\
\text { Concerns }\end{array}$ & $\begin{array}{l}\text { Environ- } \\
\text { menta } 1 \\
\text { Concerns }\end{array}$ & $\begin{array}{l}\text { Bullding } \\
\text { Code } \\
\text { Conflicts }\end{array}$ & $\begin{array}{c}\text { Legal/ } \\
\text { Regulatory } \\
\text { Difficulties }\end{array}$ & $\begin{array}{l}\text { Financing } \\
\text { Unavail- } \\
\text { ability }\end{array}$ & $\begin{array}{l}\text { High } \\
\text { Perceived } \\
\text { Risk } \\
\end{array}$ & $\begin{array}{l}\text { High } \\
\text { First } \\
\text { Cost }\end{array}$ \\
\hline
\end{tabular}

EJECTOR COUPLED HP CYCLE(a)

ELECTRODELESS HIGH-INTENSITY

$x$ DISCHARGE LIGHT

FIFTEEN-TON BRAUN LINEAR ENGINE HP.

FUEL-OIL ATOMIZATION/COMBUSTIOH

$x$

$x$

HERMETIC COMPRESSOR SEALS ${ }^{(0)}$

IH VITRO DIAGNOSTICS

$x$

$x$

$x$

IIACANOESCENT REPLACEMEHT GY H.J.D.

$\mathbf{x}$

ISOTOPICALLY ENRICHED FLUORESCENT

OTHER BARRIERS: STARTUP OF

SEPARATION BUSINESS

LOH-FIRING RATE OIL BURHEA

TECHNOLOGY

NONAZEOTROPIC REFRIGERAMT MIXTURES

OPTIMIZED GROUND COUPLEO HEAT PUAP

PERformance CONTROL STRATEgIES

SOL IO FUEL APPLIANCE MEASUREMENT METHODS

STIRLING/RANK. DIA. COUPLED HP.

SURFACE WAVE FLUORESCENT

$\boldsymbol{x}$

$x$

$x$

$x$

$x \quad x$

$x$ 


\section{TABLE B.5. (contd)}

Simple Barriers

Large

\begin{tabular}{lrl}
\hline & Large \\
Lack of Lack of & Humber of Re11- \\
Aware- & Under- & Decision abillty
\end{tabular}

Technologies

\begin{tabular}{|c|c|c|c|c|c|}
\hline $\begin{array}{l}\text { Environ- } \\
\text { menta } 1 \\
\text { Concerns }\end{array}$ & $\begin{array}{l}\text { Butlding } \\
\text { Code } \\
\text { Conflicts }\end{array}$ & $\begin{array}{c}\text { Legal/ } \\
\text { Regulatory } \\
\text { Difficulties }\end{array}$ & $\begin{array}{l}\text { Financing } \\
\text { Unavall- } \\
\text { ability }\end{array}$ & $\begin{array}{c}\text { High } \\
\text { Perceived } \\
\text { Risk } \\
\end{array}$ & $\begin{array}{l}\text { High } \\
\text { First } \\
\text { Cost Other }\end{array}$ \\
\hline
\end{tabular}

VARIABLE-SPEED COMPRESSORS \& FANS

OTHER BARRIERS: MANUFACTLRERS

DON'T PERCEIVE MARKET STRONG

ENOLGH TO SUPPORT MASS

PRODUCTION.

WOOD COMBUSTION SYSTEMS

BUILDING SERYICES DIVISION

ABSORPTION CHILLER

ACOUSTIC LEAK DETECTION SYSTEH

$\infty$ ADYANCEO DUCT SEALING TECHNIQUES

is OTHER BARRIERS: EFFECTIVE/

IMEXPEKSIVE TECHNIQUES ARE YET

TO BE DEVELOPED

adVANCED RANKINE CYCLE hEAT PUHP

AAALYTICAL TOOLS

$x$

$x$

$x$

$x$

BTU METER

COMERCIAL BUILOING RETROFIT PROCEDURES

OTHER BARRIERS: PROCEDURE HAS NOT

YET BEEN DEVEL.OPED/EVALUATED

CORE COMHERCIAL DAYLIGHTING

OTHER BARRIERS: TECHNIQUES DO NOT

EXIST AT PRESENT 
IABLE B.5. (contd)

Technologies

OIAGHOSTIC PROTOCOLS ANO ANALYSIS METHODS

OTHER BARRIERS: LOH PRIORITY ON ENERGY EFFICIENCY

OIAGNOSTIC TOOL DEVELOPHENT

OTHER BARRIERS: INEXPENSIVE AND RELIABLE DEVICES DO NOT EXIST YET

DOUH-HDLE HEAT EXCHANGER

EHERGY TRACKIHG SYSTEH

OOTHER QARRIERS: EQUIPMENT METH-

D. ODDLOGY ARE NOT YET COMPLETELY

DEVELOPED

FRICIION REDUCIIDN ADOITIVES

HEAT PUMP (QUASI OPEN CYCLE)

ICE SLURRY EVAPORATOR

INTEGRATED UTILITY PLANHING PROCESSES

MOBILE HOME RETROFIT PROCEDURES

OTHER BARRIERS: PROCEDURE HAS NOT BEEN DEVELOPED FOR CERTAIN

CLIMATIC ZONES

MULTIFAMILY AUDIT HAKDBOOK

MULTIFAMILY RETROFIT PROCEDURES

NON-METALLIC PIPING SYSTEM

\begin{tabular}{lcc}
\multicolumn{3}{c}{ Simple Barriers } \\
\hline Lack of Lack of & Number of Reli- \\
Aware- & Under- & Decision ability
\end{tabular}

Environ- Butlding

Makers Concerns

Concerns Conflicts

Serious Barrlers

$x$

Regulatory

Financting

Unavall-

High High

$x$

$x$

ablitty

Risk

R1sk

Cost Other

$x \quad x$ 
IABLE B.5. (contd)

\begin{tabular}{|c|c|c|c|c|c|c|c|c|c|c|}
\hline \multicolumn{4}{|c|}{ Stuple Barriers } & \multicolumn{7}{|c|}{ Serious Barriers } \\
\hline $\begin{array}{l}\text { Lack of } \\
\text { Aware- } \\
\text { ness }\end{array}$ & $\begin{array}{l}\text { Lack of } \\
\text { Under- } \\
\text { gtanding }\end{array}$ & $\begin{array}{l}\text { Large } \\
\text { Humber of } \\
\text { Decision } \\
\text { Makers }\end{array}$ & $\begin{array}{l}\text { Reli- } \\
\text { ability } \\
\text { Concerns }\end{array}$ & $\begin{array}{l}\text { Environ- } \\
\text { mental } \\
\text { Concerns }\end{array}$ & $\begin{array}{l}\text { Building } \\
\text { Code } \\
\text { Conflicts }\end{array}$ & $\begin{array}{l}\text { Legal/ } \\
\text { Regulatory } \\
\text { Difficulties }\end{array}$ & $\begin{array}{l}\text { Financing } \\
\text { Unavai1- } \\
\text { ability }\end{array}$ & $\begin{array}{l}\text { High } \\
\text { Perceived } \\
\text { Risk }\end{array}$ & $\begin{array}{l}\text { High } \\
\text { First } \\
\text { Cost }\end{array}$ & Other \\
\hline
\end{tabular}

OPERATING AND MAINTENANCE

PROCEDURES

PUBLIC HOUSIMG RETROFIT PROCEDURES

$\mathbf{X}$

$x$

RADIANT GARRIER CLIMATIC GUIDE

RADIANT BARRIER MODELING

SHARED SAVINGS

OTHER BARRIERS: LOW PRIORITY ON ENERGY EFFICIENCY

N

STRATEGIES FOR EMERGING ISSUES

N TECKNOLOGY ASSESSMENT AND MARKET PENETRATION

LRBAN HEAT ISLANOS

OTHER BARRIERS: MUNDANE, SIMPLE, LACKS APPEAL OF COMPLEX

VACULN STEAM RADIATORS

\section{BUILOING SYSTENS DIYISION}

ACOUSTIC TESTING OF ATTIC INSULATION

ADVANCED DESIGN TOOLS

AOVANCEO DURABLE LOW-E COATINGS OTHER BARRIERS: SCALING UP

PROCESS FROM LAB TO

PRODUCTION SCALE

ADVARCED LEAKAGE TECHHIQUES $x$

$\mathbf{x}$

$x$

$x$ $\mathrm{x}$

$x$

$x$

$x$

$\mathbf{X}$

$\mathbf{X}$

$x$

$x$ 
TABLE B.5. (contd)

\begin{tabular}{l} 
Simple Barriers \\
\hline Large \\
Lack of Lack of Mumber of Reli- \\
Aware- Under- \\
ness Decision ablitty \\
\hline
\end{tabular}

$x \quad x$

$x \quad x$

AERATEO AUTOCLAVED COHCRETE

AL TERHATIVE CFC-BASEO INSULATIONS

IN WALL AND FOUNDATIOH SYSTEMS

COMAERCIAL STAMDARDS

COMPOSITE/PRE-BUILT WALL SYSTEMS

CORROSIVENESS OF IHSULATIOH

$\stackrel{\infty}{\infty}$

\section{FIELD THERMAL PERFORMAHCE}

METHOOOLOGY

\section{FOAM AGIMG ANO R-VALUE PREOICTION}

FOUHDATIOH DESIGM TOOLS INCLUDING HANDBOOKS

HIGH-R VINDOWS

OTHER BARRIERS: MEEOS FURTHER RESEARCH

HVAC/LIGHTING INTERACTIOKS

OTHER BARRIERS: EXISTING

AMORTIZED PRODUCT LINES

IMBEODED HEAT FLUX TRAKSDUCERS

LARGE-SCALE CLIMATE SIMULATOR (LSCS)
Ser jous Barriers

$\begin{array}{cccccc}\text { Environ- } & \text { Buflding } & \text { Legal/ } & \text { Financing } & \text { High } & \text { High } \\ \text { mental } & \text { Code } & \text { Regulatory } & \text { Unavail- } & \text { Perceived First } \\ \text { Concerns } & \text { Conflicts } & \text { Difflculties } & \text { ability } & \text { Risk. } & \text { Cost }\end{array}$




\section{TABLE B.5. (contd)}

\begin{tabular}{|c|c|c|c|c|c|c|c|c|c|}
\hline \multicolumn{4}{|c|}{ Simple Barriers. } & \multicolumn{6}{|c|}{ Ser lous Barriers } \\
\hline $\begin{array}{l}\text { ack of } \\
\text { ware- } \\
\text { ness }\end{array}$ & $\begin{array}{l}\text { Lack of } \\
\text { Under- } \\
\text { standing }\end{array}$ & $\begin{array}{l}\text { Marge } \\
\text { Decistion of } \\
\text { Makers }\end{array}$ & $\begin{array}{l}\text { Reli- } \\
\text { abitity } \\
\text { Concerns }\end{array}$ & $\begin{array}{l}\text { Enviran- } \\
\text { mental } 1 \\
\text { Concerns }\end{array}$ & $\begin{array}{l}\text { Bulliding } \\
\text { Code } \\
\text { Conflicts }\end{array}$ & $\begin{array}{c}\text { Legal/ } \\
\text { Regulatory } \\
\text { Olfficulties }\end{array}$ & $\begin{array}{l}\text { Finane1ng } \\
\text { Unavall- } \\
\text { ability }\end{array}$ & $\begin{array}{c}\text { High } \\
\text { Perceived } \\
\text { Risk } \\
\end{array}$ & $\begin{array}{l}\text { High } \\
\text { First } \\
\text { Cost } \\
\end{array}$ \\
\hline
\end{tabular}

LOOSE-FILL ATIIC IMSULATION

SETTLING

MAINTENANCE AND UPGRADIHG OF DOE-2

MANUFACTUREO HOUSIMG INSULATION

MATHEMATICAL MODELING OF INDOOR AIR QUALITY

OTHER BARRIERS: VERY SMALL KUMBER OF POSSIBLE USERS

ס

MOISTURE GUIOELINES FOR RESIDENCES

Ð MOISTURE IMPACIS ON MATERIALS

MOISTURE MEASUREMENT METHODOLOGY

MULTI-ZONAL INFILTRAIION AND

OTHER BARRIERS: EXTREMELY SMALL

NUMBER OF POTENTIAL USERS

MON-INTRUSIVE MOISTURE PROBE 


\section{IABLE B.5. (contd)}

Simple Barrier Lack of Lack of Number Aware- Under- Decision Techno logies

\section{$x$}

RADIANT BARRIER SYSTEMS

RADIATIVE HEAT TRANSFER

ROOF RESEARCH CENTER - A HATIONAL USER FACILITY

RDOF SURFACE, TREATMENT GUIDEL INES

ROOF THERMAL RESEARCH APPARATUS (RTRA)

D SICK BUILDING SYMOROME

$\omega$

\section{SIMPLIFIED THERMAL ANALYSIS OF ROOFS (STAR)}

SMALL. OFFICE BUILOING HAHDBOOK OTHER BARRIERS: HIGH COST OF

RETRAINING OESIGNERS AND LACK OF FEES TO COMPENSATE FOR TRAINING LACK OF RIGHT INFO.

\section{SUBSTITUTE FOAMING AGENTS FOR} INSULATION

OTHER BARRIERS: INOETERHIMATE

STATUS OF CFC RESTRICTIONS

SUPERLITE

SHITCHABLE E MATERIALS

THERMAL BRIDGES DESIGN CATALOG
Serious Barrlers

Environ- Butlding Legal/ Flnancing High High

mental Code Regulatory Unavajl- Perceived First

Concerns Conflicts Oifftculties ability Risk Cost other

$x \quad x$

$x$

$\mathbf{x}$

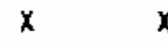

$\mathbf{x}$

$x \quad x$ 


\section{TABLE B.5. (contd)}

\begin{tabular}{|c|c|c|c|c|c|c|c|c|c|c|}
\hline \multicolumn{4}{|c|}{ Simple Barriers } & \multicolumn{7}{|c|}{ Serjous Barriers } \\
\hline & & Large & & & & & & & & \\
\hline $\begin{array}{l}\text { Lack of } \\
\text { Aware- } \\
\text { ness } \\
\end{array}$ & $\begin{array}{l}\text { Lack of } \\
\text { Under- } \\
\text { standing }\end{array}$ & $\begin{array}{l}\text { Number of } \\
\text { Decision } \\
\text { Makers }\end{array}$ & $\begin{array}{l}\text { Reli- } \\
\text { ability } \\
\text { Concerns }\end{array}$ & $\begin{array}{l}\text { Environ- } \\
\text { menta } 1 \\
\text { Concerns }\end{array}$ & $\begin{array}{l}\text { Butlding } \\
\text { Code } \\
\text { Conflicts }\end{array}$ & $\begin{array}{c}\text { Legal/ } \\
\text { Regulatory } \\
\text { Difficulties }\end{array}$ & $\begin{array}{l}\text { F1nancing } \\
\text { Unavail- } \\
\text { ability }\end{array}$ & $\begin{array}{c}\text { High } \\
\text { Perceived } \\
\text { Risk } \\
\end{array}$ & $\begin{array}{l}\text { High } \\
\text { First } \\
\text { Cost } \\
\end{array}$ & Other \\
\hline
\end{tabular}

THERMAL CONDUCTIVITY MEASUREMEHTS

ONER RANGE OF ENVIRONMENTAL

TEMPS.

VARIABLE R MATERIALS

$x$

$x$

$x$

$\mathbf{x}$

UINDON 3.1 COMPUTER PROGRAM

(a) No barriers to comercialization ident if ied. 
IABLE B.6. Commercial or Professional Organizations' Interest in the Technologies

\section{BUILDING EQUIPMENT DIVISION}

NO INTEREST INDICATED:

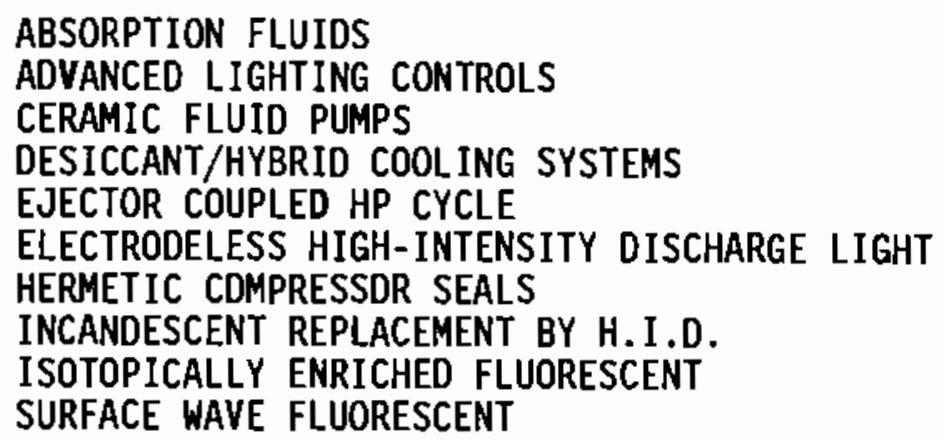

INTEREST INDICATED:

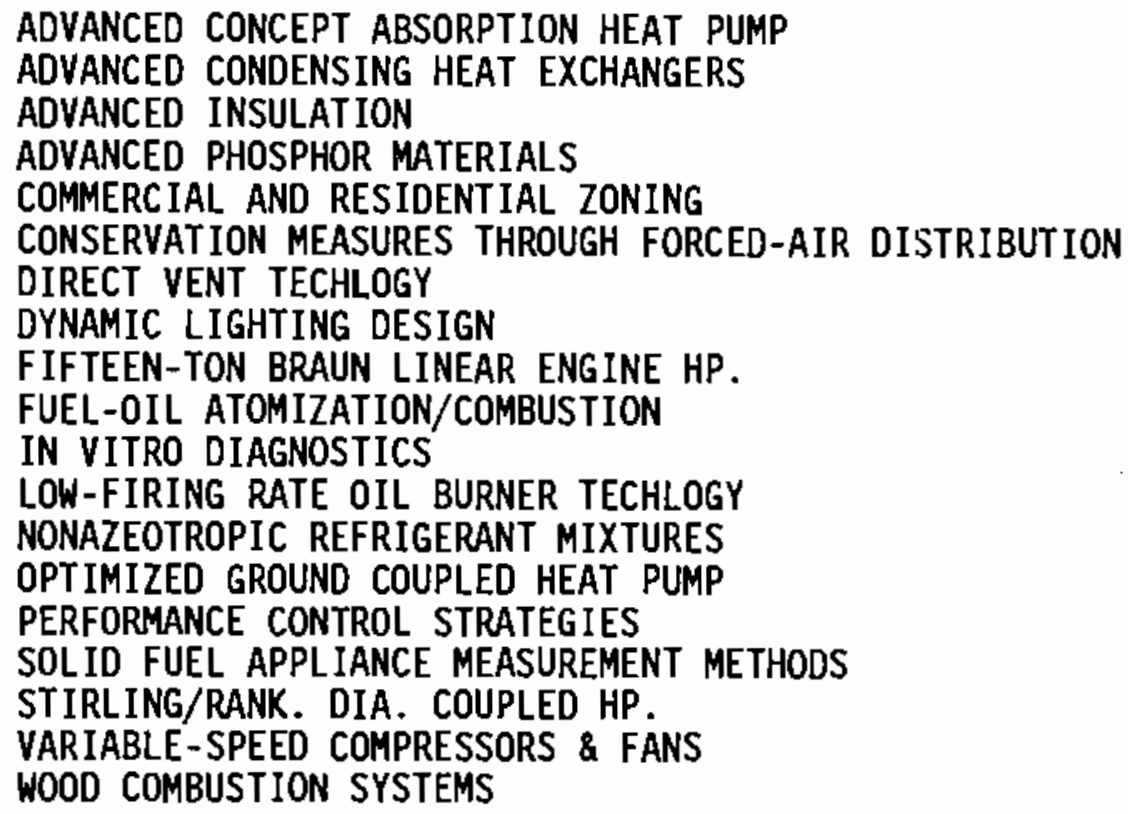

\section{BUILDING SERVICES DIVISION}

NO INTEREST INDICATED:

ADVANCED DUCT SEALING TECHNIQUES

ADVANCED RANKINE CYCLE HEAT PUMP

COMMERCIAL BUILDING RETROFIT PROCEDURES

CORE COMMERCIAL DAYLIGHTING

DIAGNOSTIC PROTOCOLS AND ANALYSIS METHODS

DIAGNOSTIC TOOL DEVELOPMENT

DOWN-HOLE HEAT EXCHANGER 
TABLE B.6. (contd)

ENERGY TRACKING SYSTEM

FRICTION REDUCTION ADDITIVES

HEAT PUMP (QUASI OPEN CYCLE)

ICE SLURRY EVAPORATOR

MOBILE HOME RETROFIT PROCEDURES

MULTIFAMILY AUDIT HANDBOOK

MULTIFAMILY RETROFIT PROCEDURES

NON-METALLIC PIPING SYSTEM

OPERATING AND MAINTENANCE PROCEDURES

PUBLIC HOUSING RETROFIT PROCEDURES

RADIANT BARRIER CLIMATIC GUIDE

RADIANT BARRIER MODELING

SHARED SAVINGS

VACUUM STEAM RADIATORS

INTEREST INDICATED:

ABSORPTION CHILLER

ACOUSTIC LEAK DETECTION SYSTEM

ANALYTICAL TOOLS

BTU METER

INTEGRATED UTILITY PLANNING PROCESSES

STRATEGIES FOR EMERGING ISSUES

TECHNOLOGY ASSESSMENT AND MARKET PENETRATION

URBAN HEAT ISLANDS

\section{BUILDING SYSTEMS DIVISION}

NO INTEREST INDICATED:

ACOUSTIC TESTING OF ATTIC INSULATION

ADVANCED DESIGN TOOLS

ADVANCED LEAKAGE TECHNIQUES

AERATED AUTOCLAVED CONCRETE

ALTERNATIVE CFC-BASED INSULATIONS IN WALL AND FOUNDATION SYSTEMS

COMPOSITE/PRE-BUILT YALL SYSTEMS

CORROSIVENESS OF INSULATION

ENERGY KERNEL SYSTEM

FIELD THERMAL PERFORMANCE METHODOLOGY

FOAM AGING AND R-VALUE PREDICTION

HVAC/LIGHTING INTERACTIONS

IMBEDDED HEAT FLUX TRANSDUCERS

LOOSE-FILL ATTIC INSULATION SETTLING

MAINTENANCE AND UPGRADING OF DOE-2

MANUFACTURED HOUSING INSULATIDN

MATHEMATICAL MODELING OF INDOOR AIR QUALITY

MOISTURE IMPACTS ON MATERIALS

MOISTURE MEASUREMENT METHODOLOGY

MULTI-ZONAL INFILTRATION AND VENTILATION MEASUREMENT 
IABLE B.6. (contd)

NON-INTRUSIVE MOISTURE PROBE

PASSIVE SAMPLER OF VOLATILE ORGANIC COMPOUNDS (VOC)

PERFLUOROCARBON TRACER SYSTEM

POWDER-FILLED EVACUATED INSULATION PANELS

PROPOR

RADIANT BARRIER SYSTEMS

RADIATIVE HEAT TRANSFER

ROOF SURFACE TREATMENT GUIDELINES

SICK BUILDING SYNDROME PROTOCOL

SIMPLIF IED THERMAL ANALYSIS OF ROOFS (STAR)

SWITCHABLE E MATERIALS

THERMAL CONDUCTIVITY MEASUREMENTS OVER RANGE OF ENVIRONMENTAL TEMPS. VARIABLE $R$ MATERIALS

INTEREST INDICATED:

ADVANCED DURABLE LOW-E COATINGS

ADVANCED RESIDENTIAL VENTILATION SYSTEMS

COMMERCIAL STANDARDS

FOUNDATION DESIGN TOOLS INCLUDING HANDBOOKS

HIGH-R WINDOWS

LARGE-SCALE CLIMATE SIMULATOR (LSCS)

MOISTURE GUIDELINES FOR RESIDENCES

ROOF RESEARCH CENTER - A NATIONAL USER FACILITY

RDOF THERMAL RESEARCH APPARATUS (RTRA)

SMALL OFFICE BUILDING HANDBOOK

SUBSTITUTE FOAMING AGENTS FOR INSULATION

SUPERLITE

THERMAL BRIDGES DESIGN CATALOG

WINDOW 3.1 COMPUTER PROGRAM 


\section{DISTRIBUTION}

No. of

Copies

OFFSITE

12 DOE Office of Scientific and Technical Information

J. P. Milhone

office of Building

Technologies

CE-13

U.S. Department of Energy

1000 Independence Avenue

Washington, DC 20585

F. H. Abel

Office of Planning and

As ses sment

U.S. Department of Energy

1000 Independence Avenue

Washington, DC 20585

J. LaMontagne

Brookhaven National Laboratory

Building 475

Upton, NY 11973

B. Farhar

Solar Energy Research

Institute

Portal Building

409 12th Street, S.W.

Suite 710

Washington, DC 20024
No. of

Copies

R. 0 . Weijo

IWTC - 7

Portland General Electric

121 S.W. SaTmon

Portland, OR 97204

ONSITE

DOE Richland Operations office

R. Goranson

26 Pacific Northwest Laboratory

R. C. Adams

E. J. Stenehjem

D. E. Deonigi

A. K. Nicholls

D. L. Shankle (10)

S. A. Weakley (3)

R. L. Eckert

M. R. Anderson

A. R. Anderson

Publishing Coordination

Technical Report Files (5) 
